\title{
Multiple roles of cardiac macrophages in heart homeostasis and failure
}

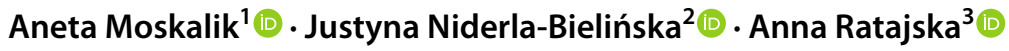

Accepted: 27 July 2021 / Published online: 13 August 2021

(c) The Author(s) 2021

\begin{abstract}
Macrophages are essential components of the immune system and play a role in the normal functioning of the cardiovascular system. Depending on their origin and phenotype, cardiac macrophages perform various functions. In a steady-state, these cells play a beneficial role in maintaining cardiac homeostasis by defending the body from pathogens and eliminating apoptotic cells, participating in electrical conduction, vessel patrolling, and arterial tone regulation. However, macrophages also take part in adverse cardiac remodeling that could lead to the development and progression of heart failure (HF) in such HF comorbidities as hypertension, obesity, diabetes, and myocardial infarction. Nevertheless, studies on detailed mechanisms of cardiac macrophage function are still in progress, and could enable potential therapeutic applications of these cells. This review aims to present the latest reports on the origin, heterogeneity, and functions of cardiac macrophages in the healthy heart and in cardiovascular diseases leading to HF. The potential therapeutic use of macrophages is also briefly discussed.
\end{abstract}

Keywords Cardiac macrophages $\cdot$ Macrophage origin $\cdot$ Cardiac macrophage phenotype $\cdot$ Macrophage functions $\cdot$ Heart failure

\section{Introduction}

Macrophages are important components of both the innate and adaptive immune response [1]. Studies on these cells date back to 1882 when Ilye Metchnikoff, a Nobel Prize laureate, based on his observations, discovered the phenomenon of phagocytosis [2,3]. According to these findings and further research macrophages are considered to be phagocytic cells (the relevant differences between macrophages, phagocytes, monocytes, and T-cells are listed in Table 1). Moreover, as a part of the adaptive immune response, macrophages are able to present antigens to $\mathrm{T}$ lymphocytes (called $\mathrm{T}$ cells), which initiate and modulate immune cell responses, and exhibit cytotoxic activity, especially towards tumor cells [1]. Unlike monocytes, which typically circulate in the bloodstream,

Anna Ratajska

anna.ratajska@wum.edu.pl

1 Postgraduate School of Molecular Medicine, Medical University of Warsaw, Warsaw, Poland

2 Department of Histology and Embryology, Medical University of Warsaw, Warsaw, Poland

3 Department of Pathology, Medical University of Warsaw, Warsaw, Poland macrophages are present in almost every tissue, where they play diverse roles in tissue homeostasis via their involvement in modulating inflammatory reactions (by secreting various mediators and/or cell-cell contact), angiogenesis, lymphangiogenesis; shaping the lymphatic vessel lumen diameter; regulating fibrosis, wound healing, metabolism in obesity and insulin resistance; sensing tissue osmotic pressure; and many others [4]. Tissue macrophages also have diverse origins (yolk-sac, fetal liver, bone marrow) and phenotypes [5]. They are generally divided into M1 and M2 populations, defined by the expression of specific (membrane bound and/or cytoplasmic) markers and the release of a plethora of mediators, cytokines, and growth factors [6]. M1 macrophages are characterized by the expression of CD80, CD86, and CD16/32 and secretion of proinflammatory cytokines, whereas M2 macrophages are anti-inflammatory and overexpress arginase-1 (Arg-1), CD206 (mannose receptor), and interleukin-10 (IL-10) [6]. However, due to the fact that macrophages are very plastic cells, the line between M1 and M2 phenotypes often blurs, which is related to macrophage-specific functions and depends on the tissue microenvironment in which they are located [4]. Nowadays, it is possible to distinguish macrophages residing in various tissues, based on different gene expression profiles and protein levels [7-9]. 


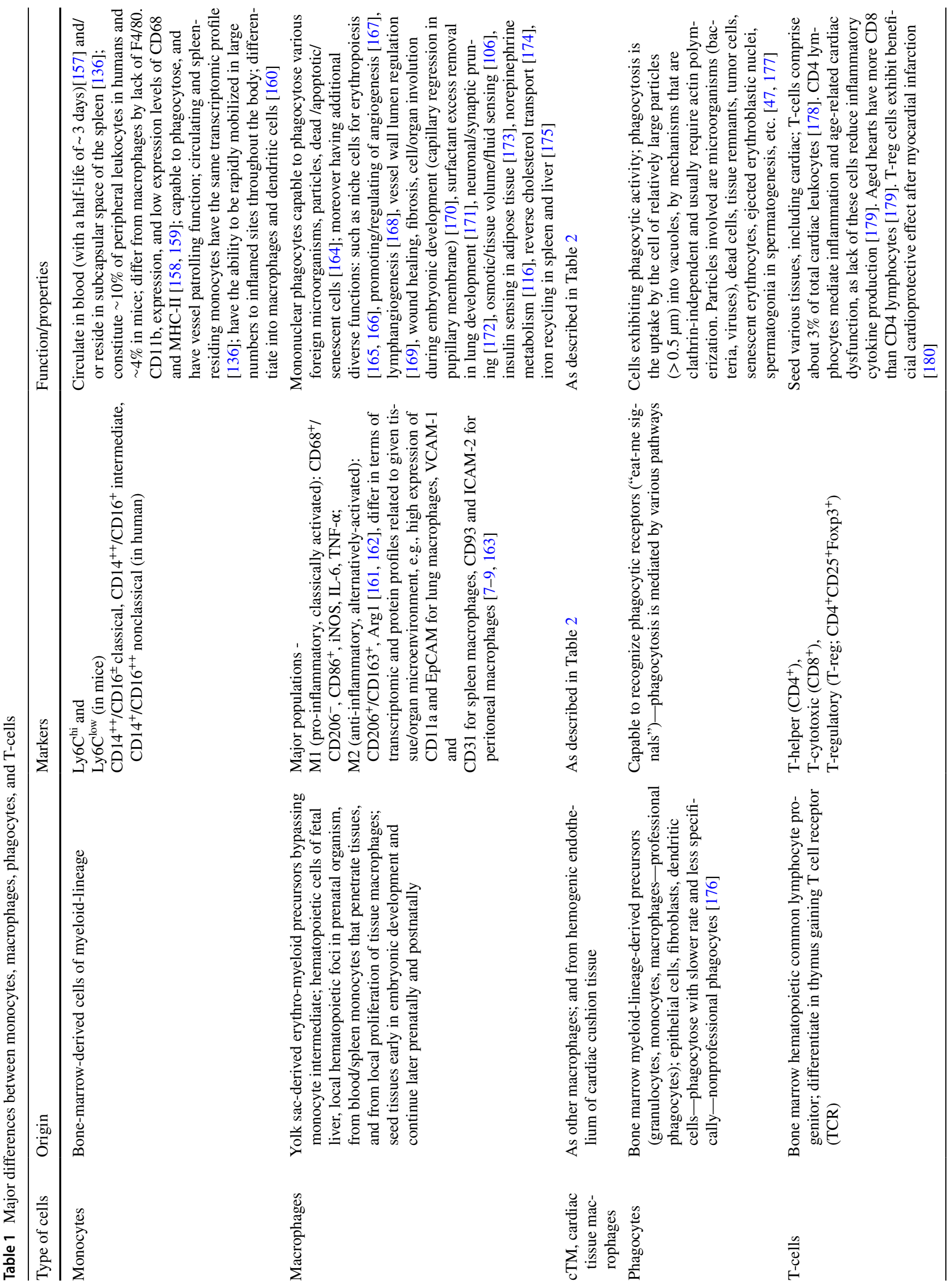


Cardiac tissue macrophages (cTMs) are immune cells located in myocardium, where they perform many functions, both in maintaining physiological tissue homeostasis and in many pathological processes. However, the mechanisms of these functions are still not fully elucidated. This review reports on the origin, heterogeneity, and functions of cTMs in healthy myocardium and in cardiovascular diseases leading to heart failure. In addition, we discuss possible future therapeutic applications with the use of (modified) macrophages.

\section{Cardiac macrophage origins}

In the past, macrophages were thought to develop only from blood monocytes [10]. However, this theory was later challenged by many authors [11-13], indicating that adult heart macrophages originate from various other sources and are able to proliferate in situ, augmenting the resident macrophage population. In addition, the origin of macrophages is believed to be related to their specific functions. Therefore, to better understand this origin-function relationship, let us take a closer look at macrophage ontogenesis.

During embryonic development, the first tissue macrophage precursors come from the yolk sac and then from fetal liver mononuclear cells, which colonize the heart and contribute to the formation of resident cardiac macrophages [14]. In the yolk sac, there are two waves of erythro-myeloid progenitors (EMPs). The first wave, beginning from embryonic day (E) 7.25 in mice, produces locally primitive erythroblasts, megakaryocytes, and macrophages without monocytic intermediates. Subsequently, at E8.25, the second wave-derived EMPs migrate into the fetal liver, where they give rise to definitive hematopoiesis, differentiating into all hematopoietic cell lineages, including monocytes [15-18]. First- and second-wave-derived EMPs could be distinguished by the lack of or dependence on c-Myb, respectively $[16,19,20]$. Primitive yolk sac macrophages migrate to the embryonic heart about E9.5, and these macrophages can be easily detected in the heart between E10.5 and E12.5 [21, 22]. The second wave, monocyte-like macrophages, which derive from the fetal liver, appear between E12.5 and E17.5. From E17.5 to adulthood, bone marrow-derived mature macrophages seed all tissues, including the heart [13, 14, 16]. Moreover, a recent report indicates hemogenic endocardium of the endocardial cushions as an additional source of cTMs. These cTMs, which emerge in developing mice at E9.5, exhibit an intensive phagocytic activity, then proliferate in situ, seeding the cushion tissue, and are indispensable for development and remodeling of the cushion tissue and, subsequently, valves [23].

Yolk sac macrophages are characterized as $\mathrm{CD} 45^{+} \mathrm{F} 4 / 80{ }^{\mathrm{hi}} \mathrm{CD} 11 \mathrm{~b}{ }^{1 \mathrm{o}} \mathrm{MHC}-\mathrm{II}{ }^{\mathrm{lo}} \mathrm{CX} 3 \mathrm{CR} 1{ }^{\text {hi }}$, while the cells derived from fetal liver monocytes are $\mathrm{CD} 45^{+} \mathrm{F} 4 / 80^{\text {lo }} \mathrm{CD} 11 \mathrm{~b}^{\text {hi }} \mathrm{CX} 3 \mathrm{CR} 1^{\text {lo }}$ [13]. Furthermore, the expression of the CCR2 marker also facilitates the distinction of macrophages by their origin. In the developing heart, $\mathrm{CCR}^{-}$macrophages derive from primitive yolk sac progenitors and colonize the subepicardial space and the subepicardial part of the myocardial wall [13, 24], whereas fetal monocyte-derived macrophages express CCR $2^{+}$and occupy the endocardial trabeculae [25]. After birth, most cardiac macrophages of embryonic origin have a high capacity for self-renewal via in situ proliferation during homeostasis $[26,27]$. However, with aging, cTM ability to proliferate gradually declines and the cells are increasingly replaced with monocyte-derived macrophages [13, 26-28]. In a healthy adult heart, all CCR $2^{+}$macrophages have been fully replaced by blood monocytes, while $70 \%$ of $\mathrm{CCR}^{-}$macrophages have self-renewed and $30 \%$ of them have been replaced by monocytes [13, 26, 29]. Interestingly, other tissue macrophages, e.g., alveolar macrophages, microglia, and Kupffer cells, are able to proliferate in situ in a steady-state, without becoming replaced by monocytes [30-32], whereas intestinal macrophages are being continuously replaced by blood-derived monocytes over the entire life span [33].

In conclusion, the adult heart consists of mixed populations of cardiac tissue macrophages in terms of their origin. The proportions of macrophages of various origins change with aging and with progression of various cardiovascular diseases, depending on the sex and on the type of cardiovascular dysfunction. Thus, macrophages may derive from embryonic precursors, blood monocytes, or hemogenic endocardium and increase in number by in situ proliferation. When homeostasis is disrupted, for example, after myocardial infarction (MI) that is associated with inflammation, blood monocytes are recruited to the heart and give rise to a new pool of macrophages [27].

\section{Cardiac tissue macrophage phenotypes}

Early studies on mouse cardiac tissue macrophages characterized them as cells bearing the $\mathrm{CD} 45^{+} \mathrm{CD} 11 \mathrm{~b}^{+} \mathrm{CX} 3 \mathrm{CR} 1^{+}$ markers [34]. Moreover, macrophages express other distinctive markers such as F4/80 and CD14, gaining CD64 and tyrosine-protein kinase Mer (MerTK) during heart development. Expressing of CD206 (Mrc1) and CD163 markers makes macrophages similar to alternatively activated M2 macrophages in a steady-state in adult mice. Mouse cTMs express negligible levels of Arg1 which is considered as a typical M2 marker [34]. There are many attempts to define cTM phenotypes and assess their subpopulations; most of these attempts are based on having selected antibodies bind with specific macrophage markers. Mouse cTMs can be characterized by various 
combinations of the absence and/or presence of CX3CR1 and MHC-II; and based on the expression of these markers, cTMs can be divided into four populations. The most numerous population and one with the most proliferative capacity is the $\mathrm{CX} 3 \mathrm{CR} 1^{+} \mathrm{MHC}-\mathrm{II}^{-}$population, which with aging, is gradually replaced by $\mathrm{CX} 3 \mathrm{CR} 1^{-}$and $\mathrm{MHC}-\mathrm{II}^{+}$ cells [26]. CX3CR $1^{+}$cells were previously reported to diminish in number with age [35]. The CX3CR1 molecule is involved in monocyte crawling or "patrolling" a vessel lumen, monocyte diapedesis across blood vessel walls, cell migration, chemotaxis, and angiogenesis, as well as apoptosis inhibition by upregulating Bcl2 required for cell survival. It is also involved in modulating inflammatory myeloid cell recruitment [36-38] (macrophage markers in relation to their functions are listed in Table 2). Ablation of CX3CR $1^{+}$macrophages increases mortality and augments peri-infarct fibrosis after myocardial infarction in mice [28]. Epelman et al., who conducted a detailed flow cytometric analysis of cardiac macrophages, showed that cTMs are represented by various populations: the main Ly6C ${ }^{-}$MHC-II ${ }^{\text {hi }} \mathrm{CX} 3 \mathrm{CR} 1{ }^{\text {hi }} \mathrm{CD} 206^{\text {int }}$ population, containing a smaller subset expressing CD11 $\mathrm{c}^{\mathrm{hi}}$, and a population expressing Ly6C $\mathrm{C}^{-} \mathrm{MHC}-\mathrm{II}{ }^{\mathrm{lo}} \mathrm{CX} 3 \mathrm{CR} 1{ }^{\mathrm{int}} \mathrm{CD} 206{ }^{\mathrm{hi}} \mathrm{CD} 11 \mathrm{c}^{\mathrm{lo}}$. Ly $6 \mathrm{C}^{+} \mathrm{MHC}-\mathrm{II}^{ \pm} \mathrm{CD} 206^{+}$cells constituted about $2 \%$ of all cTMs; moreover, a population of monocytes with a lack of MerTK and CD206 was observed [13]. Recent studies using fate mapping and single-cell transcriptomics define cTMs based on Lyve-1, MHC-II, and T-cell immunoglobulins and mucin domain-containing 4 (TIMD4) expression, the latter being involved in the clearance of apoptotic cells (efferocytosis) [28, 39, 40]. Accordingly, in a steady-state, the adult mouse heart consists of four cTM populations: TIMD $4^{+} \mathrm{LYVE}^{+}{ }^{+} \mathrm{MHC}-\mathrm{II}{ }^{\mathrm{lo}} \mathrm{CCR} 2^{-}$(self-renewable), TIMD4- ${ }^{-}$YVE $1^{-}$MHC-II ${ }^{\text {hi }}$ CCR $2^{-}$(partly replaced by monocytes), and two CCR2 $2^{+} \mathrm{MHC}-\mathrm{II}^{\mathrm{hi}}$ groups, differing by their levels of expression of various genes, such as Irf7, Ifit1, and Isg20 (entirely substituted by monocytes) [28]. CCR2 ${ }^{-}$macrophages play an important role during fetal coronary vessel development and maturation, being responsible for the selective expansion of perfused vasculature, and mediation of primitive coronary plexus remodeling [25]. In the adult heart, CCR2 ${ }^{-}$are responsible for orchestrating tissue repair [41]. CCR $2^{+}$macrophages do not have any specific function defined during heart development; however, in the adult heart with ischemia-reperfusion injury, these macrophages induce alpha-smooth muscle actin ( $\alpha$ SMA), lysyl oxidase, and collagen type 1 alpha 2 (Col1a2) expression in cultured fibroblasts, thus exhibiting profibrotic activity [42]. Additionally, cTMs support capillary homeostasis in adult myocardium and express proangiogenic factors, e.g., insulin-like growth factor 1 (IGF-1) and resistin-like molecule $\alpha$ (Rentla/ Fizz-1) [43].
A human adult heart contains similar populations of macrophages as the heart of a mouse. These cells could also be divided into CCR2 ${ }^{-}$tissue-resident macrophages, which renew through local cell proliferation, and $\mathrm{CCR} 2^{+}$cells, which derive from blood monocytes and have the ability to proliferate. Human and mouse cTMs can be distinguished based on the fact that human CCR2 ${ }^{-}$populations are mostly HLA-DR ${ }^{\text {hi }}$, while mouse $\mathrm{CCR}^{-}$populations are $\mathrm{MHC}-\mathrm{II}^{\mathrm{lo}}$ and MHC-II ${ }^{\text {hi }}$. However, no functional differences have been demonstrated so far between $\mathrm{CCR}^{-} \mathrm{MHC}-\mathrm{II}^{\mathrm{lo}}$ and $\mathrm{CCR}$ ${ }^{-}$MHC-II ${ }^{\text {hi }}$. Human CCR2- macrophages have reparative functions as well, and they express extracellular matrix components, such as SLIT3, and growth factors, such as IGF-1 and platelet-derived growth factor C (PDGF-C), whereas $\mathrm{CCR} 2^{+}$macrophages are associated with initiating inflammation, are characterized by the expression of several other receptors, and secrete chemokines, and inflammatory mediators, for instance interleukin-1 $\beta$ (IL-1 $\beta$ ), and interleukin-6 (IL-6). Moreover, inflammation-associated macrophages were shown to participate in left ventricular systolic dysfunction and express genes, such as matrix metalloprotease- 9 (MMP-9) and a metallopeptidase inhibitor 1 (TIMP1), involved in detrimental cardiac remodeling [41, 44].

Macrophages were also detected in heart valves, both in humans and in mice. Hulin et al. demonstrated the presence of various leukocyte populations in heart valves, especially in the regions of enhanced biomechanical stress (valve leaflet commissures and distal tips) [45]. Most of these leukocytes are $\mathrm{F} 4 / 80^{+}$macrophages, additionally expressing CD206 and/or MHC-II markers, and dendritic cells. Moreover, during postnatal valve development and remodeling, the number of these macrophages increases [45].

\section{The role of macrophages in the healthy cardiovascular system}

\section{Protection: phagocytosis and immune defense}

As phagocytosis is the key function of macrophages, these cells play a major role in defending the body against pathogens and eliminating apoptotic cells in a steady-state [46, 47]. After experimental infection of myocardium with parasites, the density of cardiac macrophages increases; macrophages assume stellate shapes and gain the expression of CD206, RELM $\alpha$, and YM1, markers of the M2 phenotype [48]. After infection with bacteria, resident macrophages also exhibit the ability to engulf microorganisms within a short time [27]. In addition, macrophage receptors can recognize phosphatidylserine (PtdSer) on apoptotic cell surfaces either directly (e.g., TIMD4) or indirectly (e.g., MerTK, which binds soluble "bridging" proteins, including Gas6/Pros1) [49]. One crucial regulator of activation and 
Table 2 Selected populations of cardiac macrophages and their functions

\begin{tabular}{|c|c|c|}
\hline Main function & Population of cardiac macrophages & Characteristic \\
\hline Phagocytosis & $\mathrm{MHC}-\mathrm{II}^{\mathrm{lo}} \mathrm{CCR} 2^{-}$ & $\begin{array}{l}\text { Apoptotic and necrotic cells clearance } \\
\text { The highest level of MerTK [50] }\end{array}$ \\
\hline Electrical conduction & $\begin{array}{l}\text { a) } \mathrm{MHC}-\mathrm{II}{ }^{\mathrm{hi}} \mathrm{CCR} 2^{\mathrm{hi}} \\
\text { b) } \mathrm{MHC}-\mathrm{II}^{\mathrm{hi}} \mathrm{CCR} 2^{\mathrm{lo}} \\
\text { c) } \mathrm{MHC}-\mathrm{II}^{\mathrm{lo}} \mathrm{CCR} 2^{\mathrm{lo}}\end{array}$ & $\begin{array}{l}\text { a,b) Generation of transient electrical signals, propagation of electrical signal by } \\
\text { Cx43-gap junction coupling with cardiomyocytes } \\
\text { b,c) Controlling heart rhythm and the heart beat owing to expression of ion chan- } \\
\text { nels [56] }\end{array}$ \\
\hline Vessel patrolling & $\begin{array}{l}\text { Monocytes: } \\
\text { CX3CR } 1^{\text {hi }} \text { Ly } 6 \mathrm{C}^{-} \text {(mouse) } \\
\text { CX3CR } 1{ }^{\text {hi }} \text { CD } 14^{\text {dim }}{ }^{\text {CD } 16^{+} \text {(human) }}\end{array}$ & $\begin{array}{l}\text { Recognition and removal of damaged luminal cells; scavenging micrometric } \\
\text { particles at steady-state }[37,38,62]\end{array}$ \\
\hline Arterial tone regulation & Lyve- $1^{+}$ & Regulation of vascular tone and collagen production by mural cells [63] \\
\hline Osmoregulation & TonEBP $^{+}$ & $\begin{array}{l}\text { Regulation of blood pressure, extracellular fluid, and solute volume } \\
\text { Acting via TonEBP/VEGF-C signaling pathway } \\
\text { Mediating lymphangiogenesis }[105,106]\end{array}$ \\
\hline Proinflammatory & 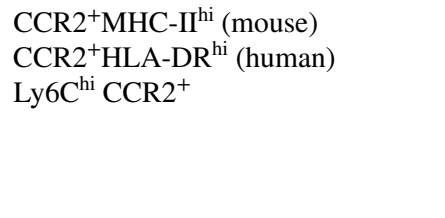 & $\begin{array}{l}\text { Monocyte-derived } \\
\text { Promote inflammatory response }[41,137,138] \text {; } \\
\text { produce IL-1b, increase cardiocyte necrosis, replacement fibrosis, worsen systolic } \\
\text { activity in acute inflammation [76]; systemic inflammation triggers CCR2 }{ }^{+} \\
\text {cardiac macrophage invasion and promote interstitial collagen deposition what } \\
\text { stiffens myocardial wall }[76,181] \text { resulting in diastolic dysfunction }\end{array}$ \\
\hline Anti-inflammatory & 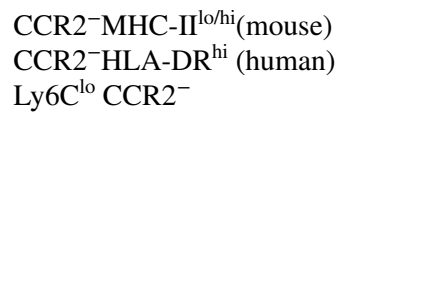 & $\begin{array}{l}\text { Embryonic origin } \\
\text { Proangiogenic function } \\
\text { Fetal coronary vessel development and maturation } \\
\text { Reparative functions }[25,41] \\
\text { Wound healing } \\
\text { Reduction of inflammation (IL-10 production) after acute phase, preservation of } \\
\text { cardiac function; } \\
\text { promotion of collagen deposition, fibrosis, and angiogenesis [142] }\end{array}$ \\
\hline Heart valve remodeling & $\begin{array}{l}\text { a) } \mathrm{CD}_{301 b^{+}} \\
\text {b) } \mathrm{CD}_{20} 206^{+}\end{array}$ & $\begin{array}{l}\text { a) Inflammation and fibrosis within the valve [148] } \\
\text { b) Tissue repair promotion and regeneration [45] }\end{array}$ \\
\hline
\end{tabular}

function of resident macrophages in healthy and injured hearts is MerTK. This receptor mediates efferocytosis and promotes anti-inflammatory response. The highest level of MerTK was reported in MHC-II ${ }^{\mathrm{lo}} \mathrm{CCR} 2^{-}$population whereas the loss of this receptor reduces efferocytosis of apoptotic cardiomyocytes [50, 51]. Moreover, cTMs secrete molecules, such as complement component 1q (C1q), galectin-1 (LGALS1), growth and differentiation factor 15 (GDF15), resolvin E1 (RvE1), that facilitate apoptotic debris clearance, inhibit leukocyte infiltration, and consequently lead to immune quiescence and a maintenance of homeostasis $[43,52]$. Other genes related to dampening local inflammation that are expressed by cTMs are the genes for IL-10, IGF-1, and V-set and immunoglobulin domain containing 4 (Vsig4) [34]. The macrophage activity to engulf apoptotic bodies has been also detected during normal heart development and is crucial to eliminate excess tissue, i.e., by shortening of the outflow tract and endocardial cushion remodeling [53, 54]. Endocardium-derived macrophages, due to their significant phagocytic ability, are essential for valve formation during embryogenesis [23].
Recent studies have shown that macrophages maintain cardiac myocyte mitochondrial homeostasis during normal energetic turnover by eliminating dysfunctional mitochondria and other impaired organelles. As defective mitochondria are released from cardiomyocytes in subcellular particles (exospheres), macrophages easily engulf them with the aid of MerTK receptors. Macrophage or MerTK ablation contributes to metabolic dysfunction of the heart. This indicates that MerTK-mediated phagocytic activity of cTMs supports normal heart function and cardiac homeostasis [55].

\section{Electrical conduction}

According to recent reports, resident macrophages located in the atrioventricular (AV) node directly modulate electrical properties of cardiac myocytes owing to macrophage coupling with cardiomyocytes via $\mathrm{Cx} 43$-containing gap junctions. This intercellular coupling leads to rhythmic macrophage depolarization and modulates the resting membrane potential and action potential of cardiomyocytes. Gene clustering of these macrophages reflects three macrophage 
subsets within the AV node: $\mathrm{MHC}-\mathrm{II}^{\mathrm{hi}} \mathrm{CCR} 2{ }^{\text {hi }}$, MHC-II ${ }^{\text {hi }} \mathrm{C}$ $\mathrm{CR} 2^{\mathrm{lo}}$, and $\mathrm{MHC}-\mathrm{II}{ }^{\mathrm{lo}} \mathrm{CCR} 2^{\mathrm{lo}}[56]$.

The first two subpopulations share genes that are responsible for generating transient electrical signals $(K c n j 2$, and $K c n q 1)$ and for propagating the electrical signal (Scn2b, whose alteration causes atrial fibrillation). Therefore, these macrophage populations are similar to AV node pacemakers. The other two macrophage subpopulations (MCHI$\mathrm{I}^{\mathrm{hi}} \mathrm{CCR} 2^{\mathrm{lo}}$ and $\mathrm{MHC}-\mathrm{II}^{\mathrm{lo}} \mathrm{CCR} 2^{\mathrm{lo}}$ ) share genes responsible for the sodium/calcium exchanger (Slc8al) and heart rhythm control $(A n k 2=$ ankyrin2), therefore, are responsible for electrical signal propagation. The sinoatrial (SA) node also contains abundant macrophages. Both human and mouse $\mathrm{SA}$ and AV node macrophages are spindle-shaped with long processes to make contact with stromal cells. $\mathrm{Cx} 43$ has low expression in the compact zone of the AV node but a higher expression in the lower nodal bundle, which may reflect a different density of gap junction-associated macrophages propagating electrical signals in separate areas of the cardiac conduction tissue. Whether other immune cells present in this area are also coupled with cardiomyocytes via $\mathrm{C} 43$-containing gap junctions has not yet been elucidated [56, 57]. In addition, macrophage depletion triggers AV block, which demonstrates their indispensability to the process of electrical conduction in the AV node in a steadystate [56]. Moreover, macrophages may cause conduction abnormalities [56], such as atrial fibrillation, ischemiainduced ventricular arrhythmias or arrhythmias associated with various inflammatory reactions (e.g., Lyme disease, Chagas, viral myocarditis) [58-61].

\section{Vessel patrolling}

A population of monocytes is involved in vessel patrolling during a steady-state and inflammation. This function is performed by crawling along healthy vessel endothelium with the involvement of lymphocyte function-associated antigen-1 (LFA-1) and CX3CR1 receptors, which also provides immune surveillance of surrounding tissues. The major function of a crawling monocyte is to recognize and remove damaged cells that arise in normal healthy tissues as a result of regular cell turnover. This mechanism is independent of the direction of blood flow and is slower than the typical rolling process. Patrolling monocytes, which are $\mathrm{Ly}_{6} \mathrm{C}^{-}$in mice and $\mathrm{CD} 14{ }^{\mathrm{dim}} \mathrm{CD} 16^{+}$in humans, have the ability to differentiate into tissue macrophages $[37,38,62]$.

\section{Arterial tone regulation}

The aorta is the main artery transporting oxygenated blood from the heart to the rest of the body. Maintaining appropriate aortic structure and function is very important, since aortic damage leads to cardiovascular diseases. In the steady-state, Lyve-1-expressing macrophages located perivascularly around the mouse aorta regulate vascular tone and collagen production by mural cells. In preventing collagen deposition, arterial fibrosis, and arterial stiffness, macrophages use a mechanism involving MMP-9 activation via Lyve-1-hyaluronan interaction [63].

\section{The role of macrophages in heart failure}

Heart failure (HF) is an increasingly common world health problem in the human population, often with poor prognosis [64]. There are three types of heart failure: HF with preserved ejection fraction (HFpEF), defined by left ventricular ejection fraction (LVEF $>50 \%$ ), HF with reduced ejection fraction (HFrEF): $\mathrm{LVEF}<40 \%$, and $\mathrm{HF}$ with midrange ejection fraction (HFmrEF): LVEF of $40-49 \%$, which differ in etiology and pathophysiology $[65,66]$. These types differ in terms of their risk factors, comorbidities, course, the cellular profile of inflammation, the extent and time course of endothelial dysfunction, as well as in terms of nitric oxide (NO) decreased bioavailability, cardiac hypertrophy and myocardial cell stiffness (due to titin modifications, perivascular, interstitial and replacement fibrosis, different levels of collagen cross-linking, altered intercellular communications, e.g., cardiac calcium signaling, and other subcellular/molecular modifications), and response to treatment [67]. A network analysis demonstrated that the biomarkers of HFpEF and HFrEF are associated with different inflammatory profile responses and different extracellular matrix reorganization [68]. In HFpEF, extracardiac comorbidities promote systemic inflammation, coronary microvascular endothelial dysfunction, interstitial fibrosis, and impaired cardiomyocyte relaxation; these pathological processes culminate in LV remodeling and diastolic dysfunction. Common extracardiac risk factors for HFpEF include advanced age, female sex, renal dysfunction, pulmonary congestion, and metabolic syndrome-associated factors such as obesity, diabetes mellitus, and hypertension. Therefore, $\mathrm{HFpEF}$ is considered to be a multisystem disorder involving the heart, lungs, kidneys, skeletal muscle, adipose tissue, vascular system, and immune and inflammatory signaling [66]. Left ventricular (LV) remodeling in HFpEF with stiff LV (diastolic dysfunction) due to more intensive deposition of collagen I than collagen III is presented by collagens deposited in the interstitium and perivascularly. Moreover, there are increased serum levels of profibrotic cytokines: monocyte chemoattractant protein 1 (MCP-1), transforming growth factor $\beta$ (TGF- $\beta$ ), and IL-6. Conversely, HFrEF is associated with cardiomyocyte cell death and consequences of inflammation, endothelial dysfunction, and replacement fibrosis, which lead to the development of systolic dysfunction. HFrEF is related to volume overload, myocardial 
infarction, myocarditis, valvular disease, and might be a result of genetic mutations $[69,70]$. HFmrEF is an intermediate stage that could progresses to HFpEF or HFrEF and appears comparable to HFrEF, at least in its responsiveness to neurohormonal blocking agents [65, 67].

Macrophages perform important functions in HF development and progression [71] (As presented on schematic Figs. 1 and 2, created using artwork from Servier Medical ART). However, detailed mechanisms are still not completely understood. Multiple pathways leading to HF seem to be triggered by macrophages, depending on the phenotypic character of these cells defined by their secretome, miRNome [72], and genetic (mRNA) profile. Nevertheless, it is known that the role of macrophages in hypertension, obesity, diabetes, renal dysfunction, which are risk factors leading to HF, is crucial [69, 70]. A thorough analysis of macrophage functions in cardiac pathologies may contribute to finding future therapeutic targets, which are particularly needed in $\mathrm{HFpEF}$, since no pharmacological agents have meaningfully improved outcomes.

Myocardial wall stiffness with diastolic dysfunction caused by interstitial fibrosis is a key characteristic of HFpEF. Profibrotic activities of macrophages have been described to proceed via various pathways. For example, macrophage-derived IL-10, which is secreted in excess during the development of diastolic dysfunction induced either by hypertension or aging, promotes profibrotic mechanisms, both in mice and humans. This process is initiated through an intensive recruitment of the circulating monocytes derived from bone marrow and spleen to the heart, which increases cardiac macrophage density [73]. Increased numbers of $\mathrm{CD} 8^{+}$macrophages and augmented fibrosis associated with inflammation were also confirmed in the aging rat model of pre-HFpEF, obese ZSF1 rats with HFpEF, and other animal models (our own observations) (Fig. 3) [74, 75]. Macrophages start to secrete IL-10, and their phenotype changes to profibrotic (characterized by the cell marker MHC-II $\left.{ }^{\mathrm{hi}}\right)$. Although IL-10 production is considered beneficial, since it dampens inflammation and promotes tissue repair, in this case, it is excessive and harmful. Increased amounts of IL-10 contribute to the production of osteopontin, galectin-3, proteases, and MMPs, which in consequence induces myofibroblast activation and deposition of collagen. This increases myocardial stiffness and promotes diastolic dysfunction $[73,76]$. It is worth noting that IL-10 could be also released by other immune cells, such as dendritic cell subsets, T-cell subpopulations, and B cells [77], by isolated cardiomyocytes stimulated by LPS [78], and by sham-operated hearts and in lesser amount by hearts after myocardial infarction [79].

HFpEF is strongly related to obesity and metabolic syndrome (MetS), which is accompanied by increased epicardial fat deposits and inflammation. After adipocyte death and independently, under the influence of hypoxia-inhibitory factor-1 $\alpha$ (HIF-1 $\alpha)$, M1-type macrophages are recruited. They release IL-1 $\beta$, IL-6, tumor necrosis factor $\alpha$ (TNF $\alpha$ ), and MCP-1, which may contribute to cardiac fibrosis and diastolic dysfunction. HIF- $1 \alpha$ promotes also a profibrotic transcriptional program in myofibroblasts, involving collagen I, III, and IV deposition, lysyl oxidase, and elevated expression of TIMP1 [80]. In a mouse model of chronic angiotensin II-induced hypertension, cTMs also release galectin-3, a protein involved in myocardial fibrosis promotion [81]. Likewise, a profibrotic profile of macrophages was demonstrated in in vitro studies, when monocytes of healthy donors cultured with HFpEF patient serum differentiated into macrophages [82].

Interestingly, macrophages take part in perivascular fibrosis, which is more severe in HFpEF than in $\mathrm{HFrEF}[83,84]$. In a pressure overload model associated with LV diastolic dysfunction, macrophage recruitment in perivascular areas is mediated by increased level of MCP-1, and intercellular adhesion molecule 1 (ICAM-1) expression on intramyocardial artery endothelial cells. As a result, macrophages secrete TGF- $\beta$ and other profibrotic cytokines, which activate fibroblast proliferation and subsequent fibrosis $[84,85]$. Excessive perivascular fibrosis causes an impaired oxygen and nutrient supply due to a diminished blood flow, which leads to adverse cardiac remodeling [86]. Moreover, MCP-1 is upregulated in the serum of patients with HFpEF compared with the MCP-1 levels in the serum of healthy individuals [87], and TGF- $\beta$ is an independent biomarker, which helps distinguish HFpEF from HFrEF [88]. Microvascular dysfunction also contributes to HFpEF. It leads to capillary rarefaction, thereby resulting in impaired blood flow and deficient tissue nutrient and oxygen supply. Macrophages stimulated with lipopolysaccharide (LPS), interferon-gamma (IFN- $\gamma$ ), or under tissue hypertensive conditions, activate Nf-кb, upregulating ICAM, MCP-1, and IL-6, thus causing endothelial cell (EC) dysfunction [89]. Recently, cardiac lymphatic vessel dysfunction and rarefaction have been described as a result of MetS. Imbalance in tissue fluid homeostasis and inflammatory cell trafficking would lead to cardiac edema, leading to fibrosis and diastolic dysfunction [90]. Moreover, considering that HFpEF is associated with systemic inflammation, microvascular ECs are activated, which prompts enhanced expression of adhesion molecules, e.g., vascular cell adhesion molecule (VCAM), ICAM-1, or E-selectin. Through upregulating NADPH oxidase 2 (NOX2) expression, macrophages promote high oxidative stress and reduce NO bioavailability. This, in turn, diminishes PKG signaling, decreases titin phosphorylation, and increases passive cardiomyocyte stiffness [75].

Ordinarily, heart diseases do not only involve dysfunctions of a single organ. There are mechanisms throughout the body that interact with each other. For instance, during heart failure in mice, proinflammatory monocytes in 


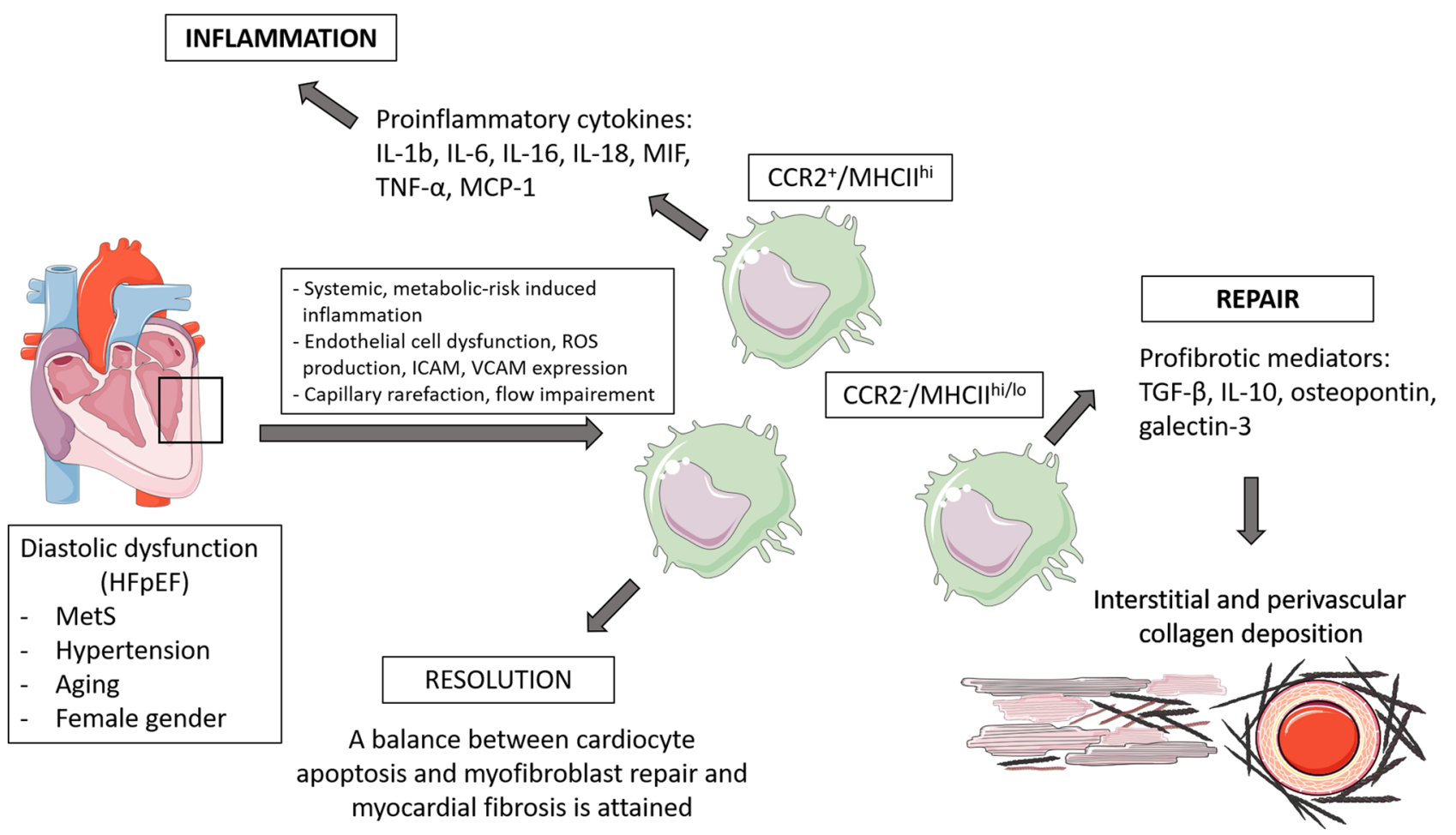

Fig. 1 Schematic presentation of major macrophage-mediated cardiac remodeling pathways in development of HFpEF

the spleen are persistently mobilized to the heart. Therefore, splenectomy decreases tissue macrophage infiltration and halts adverse myocardial remodeling [91]. Likewise, macrophages play an important role in signaling processes during the interaction between the heart, brain, and kidneys, supporting adaptive mechanisms after cardiac pressure overload. Using wild-type mice subjected to transverse aortic constriction (TAC) and CD-Klf5KO

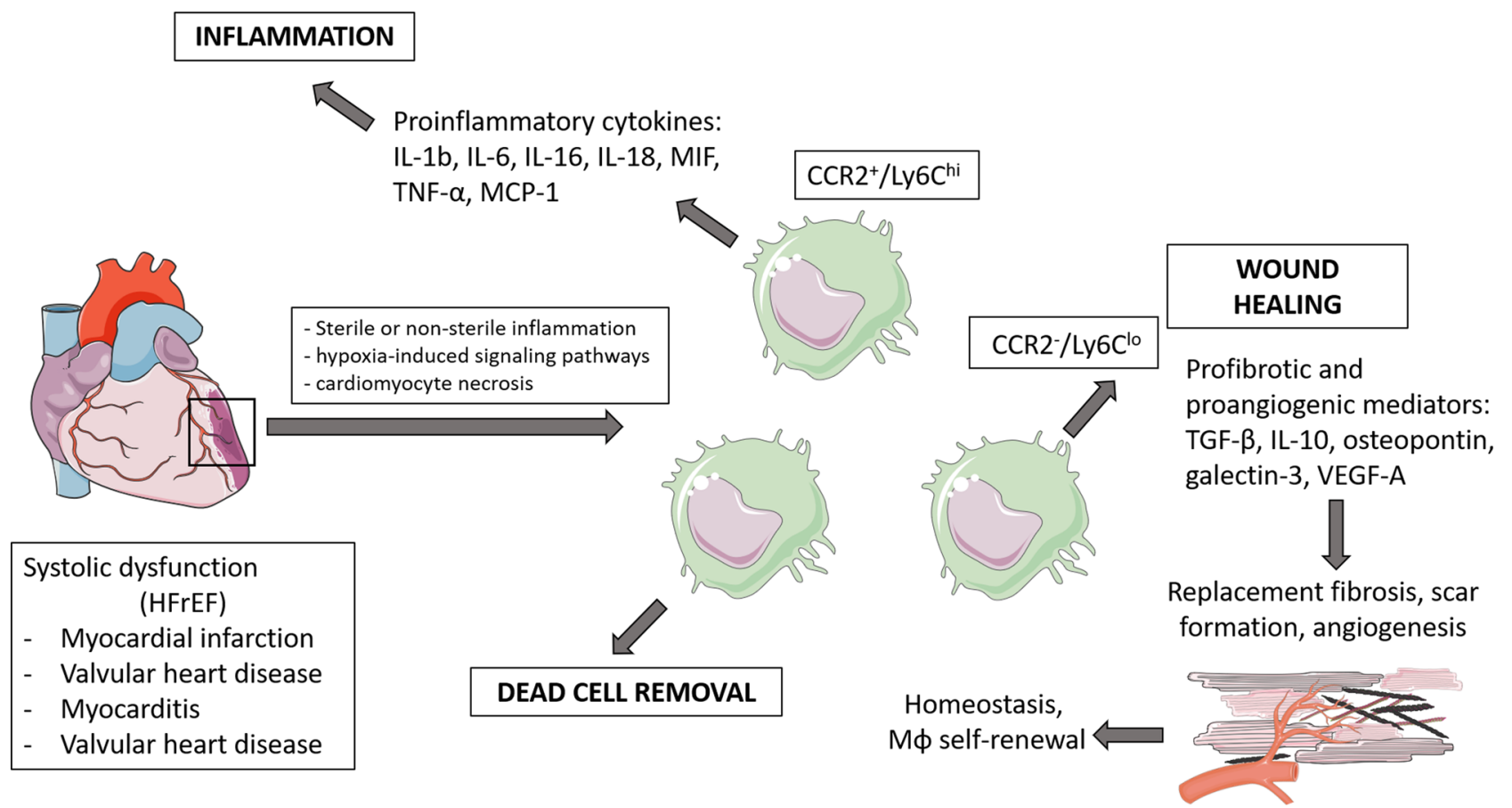

Fig. 2 Schematic presentation of major macrophage-mediated cardiac remodeling pathways in development of HFrEF 

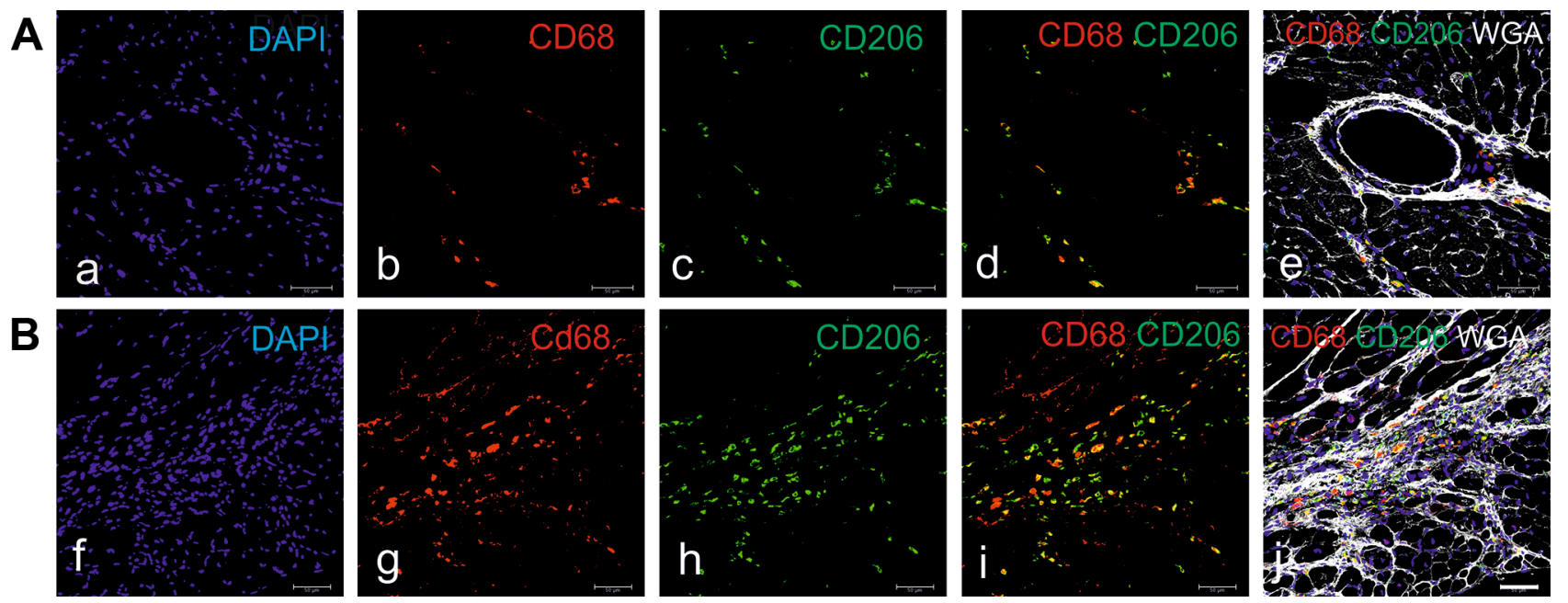

Fig. 3 Perivascular (A) and scar-associated (B) macrophages in the myocardium of hypertensive $\mathrm{db} / \mathrm{db}$ mice. $\mathrm{Db} / \mathrm{db}$ mice were treated with angiotensin II for 4 weeks via infusion from subcutaneously implanted minipumps. The hearts were harvested at the age of

mice (i.e., mice without kruppel-like factor 5 in renal collecting ducts). Fujiu et al. demonstrated that the sympathetic nervous system is activated in response to stress. Through a variety of mechanisms in the kidney and renal macrophage activity, renal endothelial cells secrete granulocyte-macrophage colony-stimulating factor (GM-CSF) into the blood circulation. GM-CSF induces the proliferation of cardiac Ly $6 \mathrm{C}^{\text {lo }}$ macrophages, which produce amphiregulin (AREG), an important cardioprotective mediator. AREG modulates adaptive cardiac hypertrophy and fibrosis [92]. Moreover, neurohormonal pathways and their interaction with the immune system are also crucial in HF progression [93].

\section{Hypertension}

Essential hypertension is characterized by chronic elevation of blood pressure and is associated with cardiovascular dysfunctions that may lead to HF. Many studies have been focused on the factors (both genetic and environmental) associated with the development of hypertension, e.g., associated with the function and regulation of the renin-angiotensin-aldosterone (RAA) system [94-96]. However, it is only in recent years that attention has been paid to immune cells, which also take part in the pathogenesis of hypertension [97-100]. Macrophages are mediators in the development of hypertension, which is associated with LV hypertrophy, cardiac remodeling, and fibrosis [101]. The level of macrophage infiltration in a hypertensive heart increases, and one of the mechanisms mediating this process is the CXCL1-CXCR2 axis [81, 102, 103].
21 weeks, frozen, and immunostained as indicated on panels. Analysis was performed under a confocal microscope (Leica, Wetzlar, Germany). WGA, wheat germ agglutinin demarcates cell borders. Scale bar, $50 \mu \mathrm{m}$

Interestingly, one of macrophage functions is the regulation of blood pressure, extracellular fluid, and solute volume. This unique role was examined in rats treated with a high-salt diet, which caused interstitial hypertonic environment in the skin. In response to sodium accumulation the number of macrophages increases, simultaneously activating the tonicity-responsive enhancer binding protein (TonEBP) which senses the osmotic tissue pressure. In response to increased tissue tonicity, macrophages exhibiting the TonEBP receptor release vascular endothelial growth factor-C (VEGF-C), thus stimulating lymphangiogenesis. Therefore, the growth of lymphatic vessels during excessive salt intake blunts an increase of blood pressure, acting as a fluid buffering system. Moreover, the elevated serum levels of VEGF-C in humans with hypertension may indicate a similar mechanism in patients $[104,105]$. Macrophage infiltration and upregulation of the TonEBP/ VEGF-C signaling pathway also occur in the myocardium of spontaneously hypertensive rats under the influence of high-salt diet. Importantly, VEGF-C secretion and cardiac lymphangiogenesis lead to severe LV remodeling, which manifests by LV enlargement and perivascular and interstitial fibrosis [106].

\section{Obesity}

Obesity is an independent risk factor of HF, as it causes hemodynamic changes that contribute to cardiac remodeling, which is manifested by changes in cardiac morphology and function [107]. Obesity correlates with worse myocardial symptoms in patients with HF [108] and greater systemic and local inflammation [109]. The level of monocytes 
increases in the circulation [110], and macrophages accumulate in the adipose tissue, especially in the epicardial adipose tissue (EAT) [111-113]. There are studies suggesting that macrophages can participate in the process of adaptive thermogenesis by the production of catecholamines [114]. However, this hypothesis has been recently challenged, showing that macrophages residing adjacent to neurons do not synthesize catecholamines [115] but are able to import and metabolize catecholamines, such as neuron-derived norepinephrine (NE) [116]. The NE transporter SLC6A2 and degradation enzyme MAOA are involved in these processes. A reduction in NE availability in the adipose tissue leads to blunted lipolysis, and thus promotes obesity [116]. Macrophages are known to be very susceptible to microenvironmental changes, particularly, to metabolic dysregulation, which is also mediated by obesity [117]. Many factors, such as hypoxia-induced signaling pathways [80, 118], metabolic substrates (e.g., fatty acids), proinflammatory lipid mediators [119-121], and hormones (e.g., leptin) [122], contribute to excessive macrophage activation. These factors stimulate a switch in the macrophage phenotype from anti-inflammatory to proinflammatory [123]. This leads to macrophages releasing proinflammatory cytokines, whose excess may contribute to microvascular abnormalities, fibrosis, and promote HF [80].

\section{Diabetes}

The course of diabetes is related to a prolonged inflammatory response, which could induce adverse cardiac remodeling and increase the risk of HF [124]. Hyperglycemia stimulates macrophage infiltration, which produces inflammatory cytokines, such as TNF- $\alpha$, IL- 6 , MCP-1, IL- $1 \beta$. These cytokines, through various mechanisms, promote chronic inflammation, fibrosis, and tissue damage [125-127]. For instance, in diabetic mice macrophage-dependent, IL-1 $\beta$ production induced by toll-like receptor 2 (TLR2) and NLRP3 inflammasome activation may lead to cardiac arrhythmias [126]. IL- $1 \beta$ induction also reduces proangiogenic and regenerative capacity of myeloid angiogenic cells (MACs) under diabetic conditions, which may contribute to ischemic disease [128]. Diabetes results in the production of advanced glycation end-products (AGEs), which induce macrophage polarization towards an $\mathrm{M} 1$ phenotype via the RAGE/NF- $\kappa B$ pathway, and the secretion of TNF- $\alpha$, IL- $1 \beta$, IL-6 by macrophages [129]. Moreover, AGEs contribute to microvascular and macrovascular complications by increasing endothelial permeability and blocking nitric oxide (NO) activity in the endothelium, which generates reactive oxygen species (ROS). AGEs also induce cross-linking of collagen, thus promoting ventricular rigidity $[130,131]$. Furthermore, in response to diabetes-related cardiac myocyte lipid overload, inflammatory pathways are activated, which often leads to lipotoxic cardiomyopathy. Macrophages are recruited to the heart even before the onset of cardiomyopathy, and the expression of their cytokines/cytokine receptors, e.g., IL-6, MCP-1, -2, -3, -5, CCR5, osteopontin, is upregulated. This leads to rapid progression of cardiac dysfunction. Depletion of macrophages reduces the expression of inflammatory markers and attenuates adverse disturbances in the heart [132].

One important aspect of diabetes is impaired macrophage phagocytic and chemotactic function, e.g., an insufficient efferocytosis of apoptotic cardiomyocytes and cellular debris [133]. In vitro studies indicated that under high glucose conditions, mir-126 expression in macrophages decreases, leading to upregulation of ADAM9 expression and MerTK cleavage. Apart from defective macrophage efferocytosis, loss of MerTK function results in a diminished capacity to resolve inflammation, which could contribute to defective organ repair. The same mechanism was also observed in human diabetic hearts [124]. These examples show how crucial is the role of macrophages in diabetes, potentially leading to heart dysfunction and damage of myocardial cells.

\section{Myocardial infarction}

Acute MI is one of the main factors leading to HFrEF. In MI, macrophages play an extremely important role, which was widely studied [134]. Already in the first minutes after the injury, a cascade of reactions is initiated. These reactions include augmented adhesion molecule expression by endothelial cells, such as selectins and VCAM1, production of damage-associated molecular patterns (DAMPs) by dying cardiomyocytes, and the production of chemokines/ cytokines, growth factors by resident macrophages, fibroblasts, and other cells [135]. This results in an influx of neutrophils, and monocytes from the bone marrow and spleen to the MI zone [136]. In the initial post-MI phase, the number of tissue-resident macrophages in the damaged region is significantly reduced, and they are replaced by proinflammatory macrophages $[27,28]$. Cardiomyocyte death affects tissue-resident CCR2 ${ }^{+}$macrophages, which through MYD88-dependent mechanisms and increased myocardial CCL2/MCP-1 expression contribute to Ly6 $\mathrm{C}^{\text {hi }}$ monocytes infiltrating the heart muscle and differentiating into proinflammatory Ly6C ${ }^{\text {hi }}$ macrophages $[137,138]$. Moreover, resident $\mathrm{CCR} 2^{+}$monocyte-derived macrophages play an essential role in neutrophil extravasation by the production of CXCL2 and CXCL5 [139]. Within the first days after $\mathrm{MI}$, the main macrophage function is the clearance of cell debris, especially dying cardiomyocytes [140]. Inflammatory cytokines, such as TNF- $\alpha$, IL- 1 , IL- 6 , and MMPs, are also released, amplifying the inflammatory process [141]. The second phase, called the reparative phase, is dominated by Ly $6 \mathrm{C}^{\text {low }}$ macrophages which could be differentiated from 
Ly6 $\mathrm{C}^{\text {hi }}$ monocytes. The transcription factor $\mathrm{Nr} 4 \mathrm{a} 1$ has been suggested to take part in switching from proinflammatory to anti-inflammatory mechanisms [137]. Ly6 $\mathrm{C}^{\text {low }}$ macrophages are required for wound healing and reducing the inflammatory reaction. These macrophages start to release IL-10 and TGF- $\beta$, which promote collagen production, fibrosis, and angiogenesis [142]. Recent studies suggest that macrophages could directly contribute collagen to scar formation in zebrafish and mouse injured hearts [143]. Interestingly, the macrophages located in the pericardial cavity and exhibiting $\mathrm{Gata}^{+}$phenotype play a cardioprotective function after MI once they enter the myocardial wall. These macrophages are also involved in preventing fibrosis in a healthy myocardium [144]. Suppression of excessive fibrosis in the heart tissue is also mediated by the Ly6C ${ }^{\text {hi }}$ macrophages that accumulate in hypoxic areas and secrete Oncostatin-M, a member of IL-6 cytokine family, which inhibits fibroblast activation by downregulating $\alpha$ SMA expression [145].

Macrophages have a profound impact on the course of inflammation, the reparative phase, and preservation of cardiac functionality. However, when the balance between pro- and anti-inflammatory phases is not maintained, for instance when the inflammatory reaction is prolonged or inadequately suppressed, it could lead to serious pathological consequences, including impaired systolic function and adverse LV remodeling [142].

\section{Heart valve pathology/remodeling}

Valvular heart dysfunction is a disease whose prevalence increases with age, with more than $10 \%$ of adults older than 75 years affected. Valvular dysfunction is frequently associated with mitral valve fibrosis and remodeling, as observed as a consequence of an autoimmune response in rheumatic heart disease [146, 147]. In a mouse model of mitral valve disease $\mathrm{CD} 301 \mathrm{~b}^{+}$, mononuclear phagocytes accumulate in the valve. These phagocytes are involved in the processes of inflammation and fibrosis within the valve and are characterized by the presence of other markers: CD11b, CD64, CX3CR1, and expression of tissue-reparative Arg-1 and FIZZ-1 and the proinflammatory cytokines IL-6 and TNF$\alpha$. These processes are accompanied by a local proliferation of myeloid cells and a recruitment of circulating cells. The latter event takes place through VCAM-1 and very late antigen-4 (VLA-4) upregulation. Likewise, studies on samples of cardiac valve tissue with human rheumatic myocarditis confirmed the presence of $\mathrm{CD}^{2} 01 \mathrm{~b}^{+}$cells in the valves [148].

Myxomatous valve disease is another valve pathology in which macrophages are involved. This disease is associated with valve leaflet thickening and extracellular matrix disruption. In the regions of aortic and mitral valves where modified heavy chain hyaluronan is deposited, there is an increased number of macrophages compared with that in the valves of healthy individuals. Proinflammatory CCR2 ${ }^{+}$ monocytes are recruited, which is likely promoted by damaged endothelial cells, increased expression of chemokines and interleukins, and hyaluronan accumulation. On the other hand, the population of $\mathrm{CD} 206^{+}$macrophages also increases. These macrophages play a role in promoting tissue repair and regeneration [45].

\section{Conclusions and future aspects}

This article aims to present the latest reports on the origin, phenotypes, and functions of cardiac tissue macrophages in healthy hearts and in cardiovascular diseases. Macrophages are necessary for proper heart development and functioning. However, in injured hearts, these cells can play beneficial and/or detrimental roles; this is often related to their phenotype, origin, accumulation in local tissue, and easy modulation by adjacent microenvironmental changes. Due to the fact that current treatments are insufficient in blocking the development and progression of heart failure, cardiac macrophages may constitute a potential therapeutic target. For instance, the population of proinflammatory $\mathrm{CCR} 2^{+}$macrophages has been suggested as a potential novel target in heart failure treatment [41]. Using CCR2-targeted siRNAs, encapsulated in a lipid nanoparticle, monocyte infiltration was reduced, which also attenuated infarct inflammation, and LV remodeling [149]. Interestingly, after ischemia/ reperfusion, cardiac stem-cell therapy induces the temporal and regional accumulation of CCR2 ${ }^{+}$and $\mathrm{CX} 3 \mathrm{CR} 1^{+}$macrophages, which rejuvenate the infarcted area and improve cardiac function [42]. Furthermore, stromal cell-derived exosomes, which modify macrophages towards a cardioprotective phenotype, are a promising tool for further therapeutic trials [150]. Therapies related to introducing modifications at the miRNA level are worth considering as well. One of mechanism which underlies cardioprotective effect is associated to exosomal transfer of miR- $181 \mathrm{~b}$ from cardiosphere-derived cells into macrophages, in a rat model of MI [151]. Moreover, post-MI nanoparticle delivery of miR-21 to cardiac macrophages was shown to switch the macrophage phenotype from pro-inflammatory to anti-inflammatory, promote angiogenesis, and reduce hypertrophy, fibrosis, diminishing an adverse myocardial remodeling [152]. Inhibition of monocyte recruitment to the heart after injury may preserve the embryonic macrophage population in the myocardium, reduce inflammation, and enhance tissue repair [24]. Treatment with Enalapril (ACE inhibitor) reduced splenic release of monocytes and their infiltration into the healing infarct, which in consequence improved the ejection fraction by $14 \%$ [153]. Moreover, targeting inflammatory cytokines and chemokines, such as IL- 1 , IL- 6 , CCL2, TGF- $\beta$, TNF- $\alpha$, could be helpful in heart failure treatment $[154,155]$. For 
instance, suppression of chemokine receptor CXCR7 inhibits M1 macrophage polarization, chemotaxis, and inflammation to improve post-MI injury [156]. Therefore, macrophages have a therapeutic potential, and a thorough understanding of their role in the progression of heart failure is crucial.

Funding ERA-CVD Research Program which is a translational R\&D program jointly funded by national funding organizations within the framework of the ERA-NET ERA-CVD. Funding agency: NCBR, Poland, grant number: ERA-CVD/LyMitDis/1/2017.

\section{Declarations}

Conflict of interest The authors declare no conflict of interest.

Open Access This article is licensed under a Creative Commons Attribution 4.0 International License, which permits use, sharing, adaptation, distribution and reproduction in any medium or format, as long as you give appropriate credit to the original author(s) and the source, provide a link to the Creative Commons licence, and indicate if changes were made. The images or other third party material in this article are included in the article's Creative Commons licence, unless indicated otherwise in a credit line to the material. If material is not included in the article's Creative Commons licence and your intended use is not permitted by statutory regulation or exceeds the permitted use, you will need to obtain permission directly from the copyright holder. To view a copy of this licence, visit http://creativecommons.org/licenses/by/4.0/.

\section{References}

1. Arts RJW, Netea MG (2016) Adaptive characteristics of innate immune responses in macrophages. Microbiol Spectr 44. https://doi.org/10.1128/microbiolspec.MCHD-0023-2015

2. Tauber AI (2003) Metchnikoff and the phagocytosis theory. Nat Rev Mol Cell Biol 411:897-901. https://doi.org/10.1038/ nrm1244

3. Kaufmann SH (2008) Immunology's foundation: the 100-year anniversary of the Nobel Prize to Paul Ehrlich and Elie Metchnikoff. Nat Immunol 97:705-712. https://doi.org/10.1038/ ni0708-705

4. Murray PJ, Wynn TA (2011) Protective and pathogenic functions of macrophage subsets. Nat Rev Immunol 1111:723-737. https://doi.org/10.1038/nri3073

5. Epelman S, Lavine KJ, Randolph GJ (2014) Origin and functions of tissue macrophages. Immunity 411:21-35. https://doi. org/10.1016/j.immuni.2014.06.013

6. Yunna C, Mengru H, Lei W, Weidong C (2020) Macrophage M1/M2 polarization. Eur J Pharmacol 877:173090. https://doi. org/10.1016/j.ejphar.2020.173090

7. Lavin Y, Winter D, Blecher-Gonen R, David E, Keren-Shaul $\mathrm{H}$, Merad M et al (2014) Tissue-resident macrophage enhancer landscapes are shaped by the local microenvironment. Cell 1596:1312-1326. https://doi.org/10.1016/j.cell.2014.11.018

8. Artyomov MN, Sergushichev A, Schilling JD (2016) Integrating immunometabolism and macrophage diversity. Semin Immunol 285:417-424. https://doi.org/10.1016/j.smim.2016. 10.004

9. Gautier EL, Shay T, Miller J, Greter M, Jakubzick C, Ivanov $S$ et al (2012) Gene-expression profiles and transcriptional regulatory pathways that underlie the identity and diversity of mouse tissue macrophages. Nat Immunol 1311:1118-1128. https://doi.org/10.1038/ni.2419

10. van Furth R, Cohn ZA (1968) The origin and kinetics of mononuclear phagocytes. J Exp Med 1283:415-435. https://doi.org/ 10.1084/jem.128.3.415

11. Jenkins SJ, Ruckerl D, Cook PC, Jones LH, Finkelman FD, van Rooijen N et al (2011) Local macrophage proliferation, rather than recruitment from the blood, is a signature of $\mathrm{TH} 2$ inflammation. Science 3326035:1284-1288. https://doi.org/10.1126/ science. 1204351

12. Sieweke MH, Allen JE (2013) Beyond stem cells: self-renewal of differentiated macrophages. Science 3426161:1242974. https:// doi.org/10.1126/science.1242974

13. Epelman S, Lavine KJ, Beaudin AE, Sojka DK, Carrero JA, Calderon B et al (2014) Embryonic and adult-derived resident cardiac macrophages are maintained through distinct mechanisms at steady state and during inflammation. Immunity 401:91-104. https://doi.org/10.1016/j.immuni.2013.11.019

14. Wang Z, Lu YL, Zhao WT, Zhong J, Lin X, Sun Z et al (2020) Distinct origins and functions of cardiac orthotopic macrophages. Basic Res Cardiol 1152:8. https://doi.org/10.1007/ s00395-019-0769-3

15. Ginhoux F, Guilliams M (2016) Tissue-resident macrophage ontogeny and homeostasis immunity 443:439-449. https://doi. org/10.1016/j.immuni.2016.02.024

16. Hoeffel G, Chen J, Lavin Y, Low D, Almeida FF, See P et al (2015) C-Myb(+) erythro-myeloid progenitor-derived fetal monocytes give rise to adult tissue-resident macrophages. Immunity 424:665-678. https://doi.org/10.1016/j.immuni.2015.03.011

17. Palis J, Robertson S, Kennedy M, Wall C, Keller G (1999) Development of erythroid and myeloid progenitors in the yolk sac and embryo proper of the mouse. Development 12622:5073-5084

18. Gomez Perdiguero E, Klapproth K, Schulz C, Busch K, Azzoni E, Crozet L et al (2015) Tissue-resident macrophages originate from yolk-sac-derived erythro-myeloid progenitors. Nature 5187540:547-551. https://doi.org/10.1038/nature13989

19. Schulz C, Perdiguero EG, Chorro L, Szabo-Rogers H, Cagnard $\mathrm{N}$, Kierdorf $\mathrm{K}$ et al (2012) A Lineage of myeloid cells independent of Myb and hematopoietic stem cells. Science 3366077:8690. https://doi.org/10.1126/science.1219179

20. León Y, Miner C, Represa J, Giraldez F (1992) Myb p75 oncoprotein is expressed in developing otic and epibranchial placodes. Dev Bio 1532:407-410. https://doi.org/10.1016/0012-1606(92) 90126-2

21. Bertrand JY, Jalil A, Klaine M, Jung S, Cumano A, Godin I (2005) Three pathways to mature macrophages in the early mouse yolk sac. Blood 1069:3004-3011. https://doi.org/10.1182/ blood-2005-02-0461

22. Stremmel C, Schuchert R, Wagner F, Thaler R, Weinberger T, Pick R et al (2018) Yolk sac macrophage progenitors traffic to the embryo during defined stages of development. Nat Commun 91:75. https://doi.org/10.1038/s41467-017-02492-2

23. Shigeta A, Huang V, Zuo J, Besada R, Nakashima Y, Lu Y et al (2019) Endocardially derived macrophages are essential for valvular remodeling. Dev Cell 485:617-630.e3. https://doi.org/10. 1016/j.devcel.2019.01.021

24. Lavine KJ, Epelman S, Uchida K, Weber KJ, Nichols CG, Schilling JD et al (2014) Distinct macrophage lineages contribute to disparate patterns of cardiac recovery and remodeling in the neonatal and adult heart. Proc Natl Acad Sci U S A 11145:16029-16034. https:// doi.org/10.1073/pnas.1406508111

25. Leid J, Carrelha J, Boukarabila H, Epelman S, Jacobsen SE, Lavine KJ (2016) Primitive embryonic macrophages are required for coronary development and maturation. Circ Res 11810:14981511. https://doi.org/10.1161/circresaha.115.308270 
26. Molawi K, Wolf Y, Kandalla PK, Favret J, Hagemeyer N, Frenzel $\mathrm{K}$ et al (2014) Progressive replacement of embryo-derived cardiac macrophages with age. J Exp Med 21111:2151-2158. https://doi. org/10.1084/jem.20140639

27. Heidt T, Courties G, Dutta P, Sager HB, Sebas M, Iwamoto Y et al (2014) Differential contribution of monocytes to heart macrophages in steady-state and after myocardial infarction. Circ Res 1152:284-295. https://doi.org/10.1161/circresaha.115.303567

28. Dick SA, Macklin JA, Nejat S, Momen A, Clemente-Casares X, Althagafi MG et al (2019) Self-renewing resident cardiac macrophages limit adverse remodeling following myocardial infarction. Nat Immunol 201:29-39. https://doi.org/10.1038/ s41590-018-0272-2

29. Zaman R, Hamidzada H, Epelman S (2021) Exploring cardiac macrophage heterogeneity in the healthy and diseased myocardium. Curr Opin Immunol 68:54-63. https://doi.org/10.1016/j. coi.2020.09.005

30. Hashimoto D, Chow A, Noizat C, Teo P, Beasley MB, Leboeuf $M$ et al (2013) Tissue-resident macrophages self-maintain locally throughout adult life with minimal contribution from circulating monocytes. Immunity 384:792-804. https://doi.org/10.1016/j. immuni.2013.04.004

31. Yona S, Kim KW, Wolf Y, Mildner A, Varol D, Breker M et al (2013) Fate mapping reveals origins and dynamics of monocytes and tissue macrophages under homeostasis. Immunity 381:7991. https://doi.org/10.1016/j.immuni.2012.12.001

32. Schulz C, Gomez Perdiguero E, Chorro L, Szabo-Rogers H, Cagnard N, Kierdorf K et al (2012) A lineage of myeloid cells independent of Myb and hematopoietic stem cells. Science 3366077:86-90. https://doi.org/10.1126/science.1219179

33. Zigmond E, Varol C, Farache J, Elmaliah E, Satpathy AT, Friedlander $\mathrm{G}$ et al (2012) Ly6C hi monocytes in the inflamed colon give rise to proinflammatory effector cells and migratory antigen-presenting cells. Immunity 376:1076-1090. https://doi.org/10.1016/j.immuni. 2012.08.026

34. Pinto AR, Paolicelli R, Salimova E, Gospocic J, Slonimsky E, Bilbao-Cortes D et al (2012) An abundant tissue macrophage population in the adult murine heart with a distinct alternativelyactivated macrophage profile. PLoS ONE 75:e36814. https://doi. org/10.1371/journal.pone.0036814

35. Pinto AR, Godwin JW, Chandran A, Hersey L, Ilinykh A, Debuque $R$ et al (2014) Age-related changes in tissue macrophages precede cardiac functional impairment. Aging (Albany NY). 65:399-413. https://doi.org/10.18632/aging.100669

36. Lee M, Lee Y, Song J, Lee J, Chang SY (2018) Tissue-specific role of CX(3)CR1 expressing immune cells and their relationships with human disease. Immune Netw 181:e5. https://doi.org/ 10.4110/in.2018.18.e5

37. Thomas G, Tacke R, Hedrick CC, Hanna RN (2015) Nonclassical patrolling monocyte function in the vasculature. Arterioscler Thromb Vasc Biol 356:1306-1316. https://doi.org/10.1161/atvbaha.114. 304650

38. Auffray C, Fogg D, Garfa M, Elain G, Join-Lambert O, Kayal $S$ et al (2007) Monitoring of blood vessels and tissues by a population of monocytes with patrolling behavior. Science 3175838:666-670. https://doi.org/10.1126/science.1142883

39. Miyanishi M, Tada K, Koike M, Uchiyama Y, Kitamura T, Nagata S (2007) Identification of Tim4 as a phosphatidylserine receptor. Nature 4507168:435-439. https://doi.org/10.1038/nature06307

40. Zaman R, Hamidzada H, Epelman S (2020) Exploring cardiac macrophage heterogeneity in the healthy and diseased myocardium. Curr Opin Immunol 68:54-63. https://doi.org/10.1016/j. coi.2020.09.005

41. Bajpai G, Schneider C, Wong N, Bredemeyer A, Hulsmans M, Nahrendorf $\mathrm{M}$ et al (2018) The human heart contains distinct macrophage subsets with divergent origins and functions. Nat Med 248:1234-1245. https://doi.org/10.1038/ s41591-018-0059-x

42. Vagnozzi RJ, Maillet M, Sargent MA, Khalil H, Johansen AKZ, Schwanekamp JA et al (2020) An acute immune response underlies the benefit of cardiac stem cell therapy. Nature 5777790:405409. https://doi.org/10.1038/s41586-019-1802-2

43. Pinto AR, Godwin JW, Rosenthal NA (2014) Macrophages in cardiac homeostasis, injury responses and progenitor cell mobilisation. Stem Cell Res 133, Part B:705-714. https://doi.org/10. 1016/j.scr.2014.06.004

44. Lindsey ML, Escobar GP, Dobrucki LW, Goshorn DK, Bouges S, Mingoia JT et al (2006) Matrix metalloproteinase-9 gene deletion facilitates angiogenesis after myocardial infarction. Am J Physiol Heart Circ Physiol 2901:H232-H239. https://doi.org/10.1152/ ajpheart.00457.2005

45. Hulin A, Anstine LJ, Kim AJ, Potter SJ, DeFalco T, Lincoln J et al (2018) Macrophage transitions in heart valve development and myxomatous valve disease. Arterioscler Thromb Vasc Biol 383:636-644. https://doi.org/10.1161/atvbaha.117.310667

46. Zent CS, Elliott MR (2017) Maxed out macs: physiologic cell clearance as a function of macrophage phagocytic capacity. Febs j 2847:1021-1039. https://doi.org/10.1111/febs.13961

47. Freeman SA, Grinstein S (2014) Phagocytosis: receptors, signal integration, and the cytoskeleton. Immunol Rev 2621:193-215. https://doi.org/10.1111/imr.12212

48. Mylonas KJ, Jenkins SJ, Castellan RF, Ruckerl D, McGregor K, Phythian-Adams AT et al (2015) The adult murine heart has a sparse, phagocytically active macrophage population that expands through monocyte recruitment and adopts an "M2" phenotype in response to Th2 immunologic challenge. Immunobiology 2207:924-933. https://doi.org/10.1016/j.imbio.2015.01.013

49. Lemke G (2019) How macrophages deal with death. Nat Rev Immunol 199:539-549. https://doi.org/10.1038/ s41577-019-0167-y

50. DeBerge M, Yeap XY, Dehn S, Zhang S, Grigoryeva L, Misener S et al (2017) MerTK cleavage on resident cardiac macrophages compromises repair after myocardial ischemia reperfusion injury. Circ Res 1218:930-940. https://doi.org/10.1161/circresaha.117.311327

51. Cai B, Kasikara C, Doran AC, Ramakrishnan R, Birge RB, Tabas I (2018) MerTK signaling in macrophages promotes the synthesis of inflammation resolution mediators by suppressing CaMKII activity. Sci Signaling 11549:eaar3721. https://doi.org/10.1126/ scisignal.aar3721

52. Fraser DA, Bohlson SS, Jasinskiene N, Rawal N, Palmarini G, Ruiz S et al (2006) C1q and MBL, components of the innate immune system, influence monocyte cytokine expression. J Leukoc Biol 801:107-116. https://doi.org/10.1189/jlb.1105683

53. Cheng G, Wessels A, Gourdie RG, Thompson RP (2002) Spatiotemporal and tissue specific distribution of apoptosis in the developing chick heart. Dev Dyn 2231:119-133. https://doi.org/ 10.1002/dvdy. 1244

54. Vicente Steijn R, Sedmera D, Blom NA, Jongbloed M, Kvasilova A, Nanka O (2018) Apoptosis and epicardial contributions act as complementary factors in remodeling of the atrioventricular canal myocardium and atrioventricular conduction patterns in the embryonic chick heart. Dev Dyn 2479:1033-1042. https://doi. org/10.1002/dvdy. 24642

55. Nicolás-Ávila JA, Lechuga-Vieco AV, Esteban-Martínez L, Sánchez-Díaz M, Díaz-García E, Santiago DJ et al (2020) A network of macrophages supports mitochondrial homeostasis in the heart. Cell 1831:94-109.e23. https://doi.org/10.1016/j.cell. 2020.08.031

56. Hulsmans M, Clauss S, Xiao L, Aguirre AD, King KR, Hanley A et al (2017) Macrophages Facilitate Electrical Conduction in the Heart. Cell 1693:510-522.e20. https://doi.org/10.1016/j.cell. 2017.03.050 
57. Grune J, Yamazoe M, Nahrendorf M (2021) Electroimmunology and cardiac arrhythmia. Nat Rev Cardiol. https://doi.org/10.1038/ s41569-021-00520-9

58. Tschöpe C, Ammirati E, Bozkurt B, Caforio ALP, Cooper LT, Felix SB et al (2021) Myocarditis and inflammatory cardiomyopathy: current evidence and future directions. Nat Rev Cardiol 183:169-193. https://doi.org/10.1038/s41569-020-00435-x

59. Kostić T, Momčilović S, Perišić ZD, Apostolović SR, Cvetković J, Jovanović A et al (2017) Manifestations of Lyme carditis. Int J Cardiol 232:24-32. https://doi.org/10.1016/j.ijcard.2016.12.169

60. Chen M, Li X, Wang S, Yu L, Tang J, Zhou S (2020) The role of cardiac macrophage and cytokines on ventricular arrhythmias. Front Physiol 111113. https://doi.org/10.3389/fphys.2020.01113

61. Sun Z, Zhou D, Xie X, Wang S, Wang Z, Zhao W et al (2016) Cross-talk between macrophages and atrial myocytes in atrial fibrillation. Basic Res Cardiol 1116:63. https://doi.org/10.1007/ s00395-016-0584-z

62. Carlin Leo M, Stamatiades Efstathios G, Auffray C, Hanna Richard N, Glover L, Vizcay-Barrena G et al (2013) Nr4a1-dependent Ly6Clow monocytes monitor endothelial cells and orchestrate their disposal. Cell 1532:362-375. https://doi.org/10.1016/j.cell. 2013.03.010

63. Lim HY, Lim SY, Tan CK, Thiam CH, Goh CC, Carbajo D et al (2018) Hyaluronan receptor LYVE-1-expressing macrophages maintain arterial tone through hyaluronan-mediated regulation of smooth muscle cell collagen. Immunity 492:326-341.e7. https:// doi.org/10.1016/j.immuni.2018.06.008

64. Benjamin EJ, Virani SS, Callaway CW, Chamberlain AM, Chang AR, Cheng S et al (2018) Heart disease and stroke statistics-2018 update: a report from the American Heart Association. Circulation 13712:e67-e492. https://doi.org/10.1161/cir.0000000000000558

65. Ponikowski P, Voors AA, Anker SD, Bueno H, Cleland JG, Coats AJ et al (2016) 2016 ESC Guidelines for the diagnosis and treatment of acute and chronic heart failure: The Task Force for the diagnosis and treatment of acute and chronic heart failure of the European Society of Cardiology (ESC). Developed with the special contribution of the Heart Failure Association (HFA) of the ESC. Eur J Heart Fail 188:891-975. https://doi.org/10.1002/ ejhf. 592

66. Mishra S, Kass DA (2021) Cellular and molecular pathobiology of heart failure with preserved ejection fraction. Nat Rev Cardiol. https://doi.org/10.1038/s41569-020-00480-6

67. Simmonds SJ, Cuijpers I, Heymans S, Jones EAV (2020) Cellular and molecular differences between HFpEF and HFrEF: a step ahead in an improved pathological understanding. Cells 91 . https://doi.org/10.3390/cells9010242

68. Tromp J, Westenbrink BD, Ouwerkerk W, van Veldhuisen DJ, Samani NJ, Ponikowski P et al (2018) Identifying pathophysiological mechanisms in heart failure with reduced versus preserved ejection fraction. J Am Coll Cardiol 7210:1081-1090. https://doi.org/10.1016/j.jacc.2018.06.050

69. Chiong M, Wang ZV, Pedrozo Z, Cao DJ, Troncoso R, Ibacache $M$ et al (2011) Cardiomyocyte death: mechanisms and translational implications. Cell Death Dis 2:e244. https://doi.org/10. 1038/cddis.2011.130

70. Dunlay SM, Roger VL, Redfield MM (2017) Epidemiology of heart failure with preserved ejection fraction. Nat Rev Cardiol 1410:591-602. https://doi.org/10.1038/nrcardio.2017.65

71. DeBerge M, Shah SJ, Wilsbacher L, Thorp EB (2019) Macrophages in heart failure with reduced versus preserved ejection fraction. Trends Mol Med 254:328-340. https://doi.org/10. 1016/j.molmed.2019.01.002

72. Niderla-Bielińska J, Ścieżyńska A, Moskalik A, JankowskaSteifer E, Bartkowiak K, Bartkowiak M et al (2021) A comprehensive miRNome analysis of macrophages isolated from $\mathrm{db} / \mathrm{db}$ mice and selected miRNAs involved in metabolic syndrome-associated cardiac remodeling. Int J Mol Sci. 224. https://doi.org/10.3390/ijms22042197

73. Hulsmans M, Sager HB, Roh JD, Valero-Munoz M, Houstis NE, Iwamoto Y et al (2018) Cardiac macrophages promote diastolic dysfunction. J Exp Med 2152:423-440. https://doi. org/10.1084/jem.20171274

74. Loredo-Mendoza ML, Ramirez-Sanchez I, Bustamante-Pozo MM, Ayala M, Navarrete V, Garate-Carrillo A et al (2020) The role of inflammation in driving left ventricular remodeling in a preHFpEF model. Exp Biol Med (Maywood):1535370220912699. https://doi.org/10.1177/1535370220912699

75. Franssen C, Chen S, Unger A, Korkmaz HI, De Keulenaer GW, Tschöpe C et al (2016) Myocardial microvascular inflammatory endothelial activation in heart failure with preserved ejection fraction. JACC Heart Fail 44:312-324. https://doi.org/ 10.1016/j.jchf.2015.10.007

76. Shen JL, Xie XJ (2020) Insight into the pro-inflammatory and profibrotic role of macrophage in heart failure with preserved ejection fraction. J Cardiovasc Pharmacol 763:276-285. https://doi.org/10.1097/fjc.0000000000000858

77. Hedrich CM, Bream JH (2010) Cell type-specific regulation of IL-10 expression in inflammation and disease. Immunol Res 471-3:185-206. https://doi.org/10.1007/s12026-009-8150-5

78. Kaur K, Sharma AK, Dhingra S, Singal PK (2006) Interplay of TNF-alpha and IL-10 in regulating oxidative stress in isolated adult cardiac myocytes. J Mol Cell Cardiol 416:1023-1030. https://doi.org/10.1016/j.yjmcc.2006.08.005

79. Kaur K, Sharma AK, Singal PK (2006) Significance of changes in TNF-alpha and IL-10 levels in the progression of heart failure subsequent to myocardial infarction. Am J Physiol Heart Circ Physiol 2911:H106-H113. https://doi.org/10.1152/ajpheart. 01327.2005

80. Warbrick I, Rabkin SW (2019) Hypoxia-inducible factor 1-alpha (HIF-1alpha) as a factor mediating the relationship between obesity and heart failure with preserved ejection fraction. Obes Rev 205:701-712. https://doi.org/10.1111/obr.12828

81. González GE, Rhaleb NE, D’Ambrosio MA, Nakagawa P, Liao TD, Peterson EL et al (2016) Cardiac-deleterious role of galectin-3 in chronic angiotensin II-induced hypertension. Am J Physiol Heart Circ Physiol 3115:H1287-h1296. https://doi.org/ 10.1152/ajpheart.00096.2016

82. Glezeva N, Voon V, Watson C, Horgan S, McDonald K, Ledwidge $\mathrm{M}$ et al (2015) Exaggerated inflammation and monocytosis associate with diastolic dysfunction in heart failure with preserved ejection fraction: evidence of M2 macrophage activation in disease pathogenesis. J Card Fail 212:167-177. https://doi.org/10.1016/j. cardfail.2014.11.004

83. Dai Z, Aoki T, Fukumoto Y, Shimokawa H (2012) Coronary perivascular fibrosis is associated with impairment of coronary blood flow in patients with non-ischemic heart failure. J Cardiol 605:416-421. https://doi.org/10.1016/j.jjcc.2012.06.009

84. Kuwahara F, Kai H, Tokuda K, Takeya M, Takeshita A, Egashira $\mathrm{K}$ et al (2004) Hypertensive myocardial fibrosis and diastolic dysfunction: another model of inflammation? Hypertension 434:739-745. https://doi.org/10.1161/01.HYP.0000118584. $33350.7 \mathrm{~d}$

85. Kuwahara F, Kai H, Tokuda K, Niiyama H, Tahara N, Kusaba K et al (2003) Roles of intercellular adhesion molecule-1 in hypertensive cardiac remodeling. Hypertension 413(Pt 2):819-823. https://doi.org/10.1161/01.Hyp.0000056108.73219.0a

86. Takeda N, Manabe I (2011) Cellular Interplay between cardiomyocytes and nonmyocytes in cardiac remodeling. Int J Inflam 2011:535241. https://doi.org/10.4061/2011/535241

87. Collier P, Watson CJ, Voon V, Phelan D, Jan A, Mak G et al (2011) Can emerging biomarkers of myocardial remodelling identify asymptomatic hypertensive patients at risk for 
diastolic dysfunction and diastolic heart failure? Eur J Heart Fail 1310:1087-1095. https://doi.org/10.1093/eurjhf/hfr079

88. Bielecka-Dabrowa A, Sakowicz A, Misztal M, von Haehling S, Ahmed A, Pietrucha T et al (2016) Differences in biochemical and genetic biomarkers in patients with heart failure of various etiologies. Int J Cardiol 221:1073-1080. https://doi.org/10. 1016/j.ijcard.2016.07.150

89. Liu S, Chen J, Shi J, Zhou W, Wang L, Fang W et al (2020) M1-like macrophage-derived exosomes suppress angiogenesis and exacerbate cardiac dysfunction in a myocardial infarction microenvironment. Basic Res Cardiol 1152:22. https://doi.org/ 10.1007/s00395-020-0781-7

90. Brakenhielm E, González A, Díez J (2020) Role of Cardiac Lymphatics in Myocardial Edema and Fibrosis: JACC Review Topic of the Week. J Am Coll Cardiol 766:735-744. https://doi.org/10. 1016/j.jacc.2020.05.076

91. Ismahil MA, Hamid T, Bansal SS, Patel B, Kingery JR, Prabhu SD (2014) Remodeling of the mononuclear phagocyte network underlies chronic inflammation and disease progression in heart failure: critical importance of the cardiosplenic axis. Circ Res 1142:266-282. https://doi.org/10.1161/CIRCRESAHA.113. 301720

92. Fujiu K, Shibata M, Nakayama Y, Ogata F, Matsumoto S, Noshita $\mathrm{K}$ et al (2017) A heart-brain-kidney network controls adaptation to cardiac stress through tissue macrophage activation. Nat Med 235:611-622. https://doi.org/10.1038/nm.4326

93. De Angelis E, Pecoraro M, Rusciano MR, Ciccarelli M, Popolo A (2019) Cross-talk between neurohormonal pathways and the immune system in heart failure: a review of the literature. Int $\mathbf{J}$ Mol Sci. 207. https://doi.org/10.3390/ijms20071698

94. Kawarazaki H, Ando K, Fujita M, Matsui H, Nagae A, Muraoka $\mathrm{K}$ et al (2011) Mineralocorticoid receptor activation: a major contributor to salt-induced renal injury and hypertension in young rats. Am J Physiol Renal Physiol 3006:F1402-F1409. https://doi.org/10.1152/ajprenal.00691.2010

95. Ekmekcioglu C, Blasche G, Dorner TE (2013) Too much salt and how we can get rid of it. Forsch Komplementmed 206:454-460. https://doi.org/10.1159/000357413

96. Giles TD, Materson BJ, Cohn JN, Kostis JB (2009) Definition and classification of hypertension: an update. The Journal of Clinical Hypertension 1111:611-614. https://doi.org/10.1111/j. 1751-7176.2009.00179.x

97. Chen XH, Ruan CC, Ge Q, Ma Y, Xu JZ, Zhang ZB et al (2018) Deficiency of complement $\mathrm{C} 3 \mathrm{a}$ and $\mathrm{C} 5 \mathrm{a}$ receptors prevents angiotensin II-induced hypertension via regulatory T cells. Circ Res 1227:970-983. https://doi.org/10.1161/circresaha.117.312153

98. Guzik TJ, Hoch NE, Brown KA, McCann LA, Rahman A, Dikalov $\mathrm{S}$ et al (2007) Role of the $\mathrm{T}$ cell in the genesis of angiotensin II induced hypertension and vascular dysfunction. J Exp Med 20410:2449-2460. https://doi.org/10.1084/jem.20070657

99. Chan CT, Sobey CG, Lieu M, Ferens D, Kett MM, Diep H et al (2015) Obligatory role for B cells in the development of angiotensin II-dependent hypertension. Hypertension 665:1023-1033. https://doi.org/10.1161/hypertensionaha.115.05779

100. Kirabo A, Fontana V, de Faria AP, Loperena R, Galindo CL, Wu $\mathrm{J}$ et al (2014) DC isoketal-modified proteins activate T cells and promote hypertension. J Clin Invest 12410:4642-4656. https:// doi.org/10.1172/jci74084

101. Kain D, Amit U, Yagil C, Landa N, Naftali-Shani N, Molotski $\mathrm{N}$ et al (2016) Macrophages dictate the progression and manifestation of hypertensive heart disease. Int J Cardiol 203:381395. https://doi.org/10.1016/j.ijcard.2015.10.126

102. Wang L, Zhang YL, Lin QY, Liu Y, Guan XM, Ma XL et al (2018) CXCL1-CXCR2 axis mediates angiotensin II-induced cardiac hypertrophy and remodelling through regulation of monocyte infiltration. Eur Heart J 3920:1818-1831. https:// doi.org/10.1093/eurheartj/ehy085

103. Zhang YL, Geng C, Yang J, Fang J, Yan X, Li PB et al (2019) Chronic inhibition of chemokine receptor CXCR2 attenuates cardiac remodeling and dysfunction in spontaneously hypertensive rats. Biochimica et Biophysica Acta (BBA) - molecular basis of disease. 186512:165551. https://doi.org/10.1016/j. bbadis.2019.165551

104. Machnik A, Neuhofer W, Jantsch J, Dahlmann A, Tammela T, Machura K et al (2009) Macrophages regulate salt-dependent volume and blood pressure by a vascular endothelial growth factor-C-dependent buffering mechanism. Nat Med 155:545552. https://doi.org/10.1038/nm.1960

105. Marvar PJ, Gordon FJ, Harrison DG (2009) Blood pressure control: salt gets under your skin. Nat Med 155:487-488. https://doi.org/10.1038/nm0509-487

106. Yang GH, Zhou X, Ji WJ, Liu JX, Sun J, Dong Y et al (2017) VEGF-C-mediated cardiac lymphangiogenesis in high salt intake accelerated progression of left ventricular remodeling in spontaneously hypertensive rats. Clin Exp Hypertens 398:740747. https://doi.org/10.1080/10641963.2017.1324478

107. Alpert MA, Lavie CJ, Agrawal H, Aggarwal KB, Kumar SA (2014) Obesity and heart failure: epidemiology, pathophysiology, clinical manifestations, and management. Transl Res 1644:345-356. https://doi.org/10.1016/j.trsl.2014.04.010

108. Obokata M, Reddy YNV, Pislaru SV, Melenovsky V, Borlaug BA (2017) Evidence supporting the existence of a distinct obese phenotype of heart failure with preserved ejection fraction. Circulation 1361:6-19. https://doi.org/10.1161/circulationaha.116. 026807

109. Lumeng CN, Saltiel AR (2011) Inflammatory links between obesity and metabolic disease. J Clin Investig 1216:21112117. https://doi.org/10.1172/JCI57132

110. Poitou C, Dalmas E, Renovato M, Benhamo V, Hajduch F, Abdennour M et al (2011) CD14dimCD16+ and CD14+CD16+ monocytes in obesity and during weight loss: relationships with fat mass and subclinical atherosclerosis. Arterioscler Thromb Vasc Biol 3110:2322-2330. https://doi.org/10.1161/atvbaha. 111.230979

111. Weisberg SP, McCann D, Desai M, Rosenbaum M, Leibel RL, Ferrante AW Jr (2003) Obesity is associated with macrophage accumulation in adipose tissue. J Clin Invest 11212:17961808. https://doi.org/10.1172/jci19246

112. Hirata Y, Kurobe H, Akaike M, Chikugo F, Hori T, Bando Y et al (2011) Enhanced inflammation in epicardial fat in patients with coronary artery disease. Int Heart J 523:139-142. https:// doi.org/10.1536/ihj.52.139

113. Butcovan D, Mocanu V, Timofte DV, Costan VV, Danila R, Veselin AP et al (2020) Macrophage accumulation and angiogenesis in epicardial adipose tissue in cardiac patients with or without chronic heart failure. Appl Sci 1017:5871

114. Nguyen KD, Qiu Y, Cui X, Goh YP, Mwangi J, David T et al (2011) Alternatively activated macrophages produce catecholamines to sustain adaptive thermogenesis. Nature 4807375:104108. https://doi.org/10.1038/nature 10653

115. Fischer K, Ruiz HH, Jhun K, Finan B, Oberlin DJ, van der Heide V et al (2017) Alternatively activated macrophages do not synthesize catecholamines or contribute to adipose tissue adaptive thermogenesis. Nat Med 235:623-630. https://doi.org/ $10.1038 / \mathrm{nm} .4316$

116. Pirzgalska RM, Seixas E, Seidman JS, Link VM, Sanchez NM, Mahu I et al (2017) Sympathetic neuron-associated macrophages contribute to obesity by importing and metabolizing norepinephrine. Nat Med 2311:1309-1318. https://doi.org/10. 1038/nm.4422 
117. Thapa B, Lee K (2019) Metabolic influence on macrophage polarization and pathogenesis. BMB Rep 526:360-372. https:// doi.org/10.5483/BMBRep.2019.52.6.140

118. Fujisaka S, Usui I, Ikutani M, Aminuddin A, Takikawa A, Tsuneyama K et al (2013) Adipose tissue hypoxia induces inflammatory M1 polarity of macrophages in an HIF-1 $\alpha$ dependent and HIF-1 $\alpha$-independent manner in obese mice. Diabetologia 566:1403-1412. https://doi.org/10.1007/ s00125-013-2885-1

119. Namgaladze D, Brune B (2016) Macrophage fatty acid oxidation and its roles in macrophage polarization and fatty acid-induced inflammation. Biochim Biophys Acta 186111:1796-1807. https://doi.org/10.1016/j.bbalip.2016.09.002

120. Kain V, Halade GV (2019) Immune responsive resolvin D1 programs peritoneal macrophages and cardiac fibroblast phenotypes in diversified metabolic microenvironment. J Cell Physiol 2344:3910-3920. https://doi.org/10.1002/jcp.27165

121. Kain V, Ingle KA, Kachman M, Baum H, Shanmugam G, Rajasekaran NS et al (2018) Excess $\omega-6$ fatty acids influx in aging drives metabolic dysregulation, electrocardiographic alterations, and low-grade chronic inflammation. American Journal of Physiology-Heart and Circulatory Physiology 3142:H160-H169. https://doi.org/10.1152/ajpheart.00297.2017

122. Dib LH, Ortega MT, Fleming SD, Chapes SK, Melgarejo T (2014) Bone marrow leptin signaling mediates obesity-associated adipose tissue inflammation in male mice. Endocrinology 1551:40-46. https://doi.org/10.1210/en.2013-1607

123. Lumeng CN, Bodzin JL, Saltiel AR (2007) Obesity induces a phenotypic switch in adipose tissue macrophage polarization. $\mathrm{J}$ Clin Invest 1171:175-184. https://doi.org/10.1172/jci29881

124. Suresh Babu S, Thandavarayan RA, Joladarashi D, Jeyabal P, Krishnamurthy S, Bhimaraj A et al (2016) MicroRNA-126 overexpression rescues diabetes-induced impairment in efferocytosis of apoptotic cardiomyocytes. Sci Rep 61:36207. https://doi.org/ $10.1038 /$ srep36207

125. Chen H, Yang X, Lu K, Lu C, Zhao Y, Zheng S et al (2017) Inhibition of high glucose-induced inflammation and fibrosis by a novel curcumin derivative prevents renal and heart injury in diabetic mice. Toxicol Lett 278:48-58. https://doi.org/10.1016/j. toxlet.2017.07.212

126. Monnerat G, Alarcon ML, Vasconcellos LR, Hochman-Mendez C, Brasil G, Bassani RA et al (2016) Macrophage-dependent IL1 beta production induces cardiac arrhythmias in diabetic mice. Nat Commun 7:13344. https://doi.org/10.1038/ncomms13344

127. Russo I, Frangogiannis NG (2016) Diabetes-associated cardiac fibrosis: cellular effectors, molecular mechanisms and therapeutic opportunities. J Mol Cell Cardiol 90:84-93. https://doi.org/ 10.1016/j.yjmcc.2015.12.011

128. Chambers SEJ, O'Neill CL, Guduric-Fuchs J, McLoughlin KJ, Liew A, Egan AM et al (2018) The vasoreparative function of myeloid angiogenic cells is impaired in diabetes through the induction of IL1beta. Stem Cells. https://doi.org/10.1002/stem. 2810

129. Jin X, Yao T, Zhou Z, Zhu J, Zhang S, Hu W et al (2015) Advanced glycation end products enhance macrophages polarization into M1 phenotype through activating RAGE/NF- $\mathrm{KB}$ pathway. Biomed Res Int 2015:732450. https://doi.org/10.1155/2015/ 732450

130. Goldin A, Beckman JA, Schmidt AM, Creager MA (2006) Advanced glycation end products. Circulation 1146:597-605. https://doi.org/10.1161/CIRCULATIONAHA.106.621854

131. Wagner JUG, Dimmeler S (2020) Cellular cross-talks in the diseased and aging heart. J Mol Cell Cardiol 138:136-146. https:// doi.org/10.1016/j.yjmcc.2019.11.152

132. Schilling JD, Machkovech HM, Kim AH, Schwendener R, Schaffer JE (2012) Macrophages modulate cardiac function in lipotoxic cardiomyopathy. Am J Physiol Heart Circ Physiol 30311:H1366-H1373. https://doi.org/10.1152/ajpheart.00111. 2012

133. Bajpai A, Tilley DG (2018) The role of leukocytes in diabetic cardiomyopathy. Front Physiol 9:1547. https://doi.org/10.3389/ fphys.2018.01547

134. Duncan SE, Gao S, Sarhene M, Coffie JW, Linhua D, Bao X et al (2020) Macrophage activities in myocardial infarction and heart failure. Cardiol Res Pract 2020:4375127. https://doi.org/10.1155/ 2020/4375127

135. Ong SB, Hernández-Reséndiz S, Crespo-Avilan GE, Mukhametshina RT, Kwek XY, Cabrera-Fuentes HA et al (2018) Inflammation following acute myocardial infarction: multiple players, dynamic roles, and novel therapeutic opportunities. Pharmacol Ther 186:73-87. https://doi.org/10.1016/j.pharmthera.2018.01.001

136. Swirski FK, Nahrendorf M, Etzrodt M, Wildgruber M, Cortez-Retamozo V, Panizzi P et al (2009) Identification of splenic reservoir monocytes and their deployment to inflammatory sites. Science 3255940:612-616. https://doi.org/10.1126/science.1175202

137. Hilgendorf I, Gerhardt LM, Tan TC, Winter C, Holderried TA, Chousterman BG et al (2014) Ly-6Chigh monocytes depend on $\mathrm{Nr} 4 \mathrm{a} 1$ to balance both inflammatory and reparative phases in the infarcted myocardium. Circ Res 11410:1611-1622. https://doi. org/10.1161/CIRCRESAHA.114.303204

138. Bajpai G, Bredemeyer A, Li W, Zaitsev K, Koenig AL, Lokshina I et al (2019) Tissue resident CCR2- and CCR2+ cardiac macrophages differentially orchestrate monocyte recruitment and fate specification following myocardial injury. Circ Res 1242:263278. https://doi.org/10.1161/circresaha.118.314028

139. Li W, Hsiao HM, Higashikubo R, Saunders BT, Bharat A, Goldstein DR et al (2016) Heart-resident CCR2(+) macrophages promote neutrophil extravasation through TLR9/MyD88/CXCL5 signaling. JCI Insight 112. https://doi.org/10.1172/jci.insight.87315

140. Wan E, Yeap XY, Dehn S, Terry R, Novak M, Zhang S et al (2013) Enhanced efferocytosis of apoptotic cardiomyocytes through myeloid-epithelial-reproductive tyrosine kinase links acute inflammation resolution to cardiac repair after infarction. Circ Res 1138:1004-1012. https://doi.org/10.1161/circresaha. 113.301198

141. Nian M, Lee P, Khaper N, Liu P (2004) Inflammatory cytokines and postmyocardial infarction remodeling. Circ Res 9412:15431553.https://doi.org/10.1161/01.RES.0000130526.20854.fa

142. Yap J, Cabrera-Fuentes HA, Irei J, Hausenloy DJ, Boisvert WA (2019) Role of Macrophages in Cardioprotection. Int J Mol Sci. 2010. https://doi.org/10.3390/ijms20102474

143. Simões FC, Cahill TJ, Kenyon A, Gavriouchkina D, Vieira JM, Sun X et al (2020) Macrophages directly contribute collagen to scar formation during zebrafish heart regeneration and mouse heart repair. Nat Commun 111:600. https://doi.org/10.1038/ s41467-019-14263-2

144. Deniset JF, Belke D, Lee WY, Jorch SK, Deppermann C, Hassanabad AF et al (2019) Gata6(+) pericardial cavity macrophages relocate to the injured heart and prevent cardiac fibrosis. Immunity 511:131-140. e5. https://doi.org/10.1016/j.immuni.2019.06.010

145. Abe $\mathrm{H}$, Takeda $\mathrm{N}$, Isagawa $\mathrm{T}$, Semba $\mathrm{H}$, Nishimura S, Morioka MS et al (2019) Macrophage hypoxia signaling regulates cardiac fibrosis via Oncostatin M. Nat Commun 101:2824. https://doi. org/10.1038/s41467-019-10859-w

146. Nkomo VT, Gardin JM, Skelton TN, Gottdiener JS, Scott CG, Enriquez-Sarano M (2006) Burden of valvular heart diseases: a population-based study. Lancet 3689540:1005-1011. https://doi. org/10.1016/s0140-6736(06)69208-8

147. Marijon E, Mirabel M, Celermajer DS, Jouven X (2012) Rheumatic heart disease. Lancet 3799819:953-964. https://doi.org/ 10.1016/s0140-6736(11)61171-9 
148. Meier LA, Auger JL, Engelson BJ, Cowan HM, Breed ER, GonzalezTorres MI et al (2018) CD301b/MGL2(+) mononuclear phagocytes orchestrate autoimmune cardiac valve inflammation and fibrosis. Circulation 13723:2478-2493. https://doi.org/10.1161/circulationaha. 117.033144

149. Majmudar MD, Keliher EJ, Heidt T, Leuschner F, Truelove J, Sena BF et al (2013) Monocyte-directed RNAi targeting CCR2 improves infarct healing in atherosclerosis-prone mice. Circulation. 12720:2038-2046. https://doi.org/10.1161/CIRCULATIONAHA. 112.000116

150. de Couto G (2019) Macrophages in cardiac repair: environmental cues and therapeutic strategies. Exp Mol Med 5112:1-10. https:// doi.org/10.1038/s12276-019-0269-4

151. de Couto G, Gallet R, Cambier L, Jaghatspanyan E, Makkar N, Dawkins JF et al (2017) Exosomal MicroRNA transfer into macrophages mediates cellular postconditioning. Circulation 1362:200-214. https://doi.org/10.1161/circulationaha.116. 024590

152. Bejerano T, Etzion S, Elyagon S, Etzion Y, Cohen S (2018) Nanoparticle delivery of miRNA-21 mimic to cardiac macrophages improves myocardial remodeling after myocardial infarction. Nano Lett 189:5885-5891. https://doi.org/10.1021/acs.nanolett. $8 \mathrm{~b} 02578$

153. Leuschner F, Panizzi P, Chico-Calero I, Lee WW, Ueno T, Cortez-Retamozo V et al (2010) Angiotensin-converting enzyme inhibition prevents the release of monocytes from their splenic reservoir in mice with myocardial infarction. Circ Res 10711:1364-1373. https://doi.org/10.1161/circresaha.110. 227454

154. Hanna A, Frangogiannis NG (2020) Inflammatory cytokines and chemokines as therapeutic targets in heart failure. Cardiovasc Drugs Ther. https://doi.org/10.1007/s10557-020-07071-0

155. Dobaczewski M, Chen W, Frangogiannis NG (2011) Transforming growth factor (TGF)- $\beta$ signaling in cardiac remodeling. J Mol Cell Cardiol 514:600-606. https://doi.org/10.1016/j.yjmcc.2010. 10.033

156. Zhang J, Zhang Y, Xin S, Wu M, Zhang Y, Sun L (2020) CXCR7 suppression modulates macrophage phenotype and function to ameliorate post-myocardial infarction injury. Inflamm Res 695:523-532. https://doi.org/10.1007/s00011-020-01335-z

157. Ziegler-Heitbrock L (2014) Reprint of: Monocyte subsets in man and other species. Cell Immunol 2911-2:11-15. https://doi.org/ 10.1016/j.cellimm.2014.06.008

158. Ginhoux F, Jung S (2014) Monocytes and macrophages: developmental pathways and tissue homeostasis. Nat Rev Immunol 146:392-404. https://doi.org/10.1038/nri3671

159. Peet C, Ivetic A, Bromage DI, Shah AM (2020) Cardiac monocytes and macrophages after myocardial infarction. Cardiovasc Res 1166:1101-1112. https://doi.org/10.1093/cvr/cvz336

160. Guilliams M, Mildner A, Yona S (2018) Developmental and functional heterogeneity of monocytes. Immunity 494:595-613. https://doi.org/10.1016/j.immuni.2018.10.005

161. Mantovani A, Sica A, Sozzani S, Allavena P, Vecchi A, Locati M (2004) The chemokine system in diverse forms of macrophage activation and polarization. Trends Immunol 2512:677-686. https://doi.org/10.1016/j.it.2004.09.015

162. Murray PJ (2017) Macrophage Polarization. Annu Rev Physiol 79:541-566. https://doi.org/10.1146/annurev-physiol-022516-034339

163. Orecchioni M, Ghosheh Y, Pramod AB, Ley K (2019) Macrophage polarization: different gene signatures in M1(LPS+) vs. classically and M2(LPS-) vs. alternatively activated macrophages. Front Immunol 10:1084. https://doi.org/10.3389/ fimmu.2019.01084

164. de Back DZ, Kostova EB, van Kraaij M, van den Berg TK, van Bruggen $\mathrm{R}$ (2014) Of macrophages and red blood cells; a complex love story. Front Physiol 5:9. https://doi.org/10.3389/ fphys.2014.00009

165. Chow A, Huggins M, Ahmed J, Hashimoto D, Lucas D, Kunisaki Y et al (2013) CD169(+) macrophages provide a niche promoting erythropoiesis under homeostasis and stress. Nat Med 194:429436. https://doi.org/10.1038/nm.3057

166. Zou Z, Enis DR, Bui H, Khandros E, Kumar V, Jakus Z et al (2013) The secreted lymphangiogenic factor CCBE1 is essential for fetal liver erythropoiesis. Blood 12116:3228-3236. https:// doi.org/10.1182/blood-2012-10-462689

167. DeFalco T, Bhattacharya I, Williams AV, Sams DM, Capel B (2014) Yolk-sac-derived macrophages regulate fetal testis vascularization and morphogenesis. Proc Natl Acad Sci U S A 11123:E2384-E2393. https://doi.org/10.1073/pnas.1400057111

168. Corliss BA, Azimi MS, Munson JM, Peirce SM, Murfee WL (2016) Macrophages: an inflammatory link between angiogenesis and lymphangiogenesis. Microcirculation 232:95-121. https:// doi.org/10.1111/micc.12259

169. Fantin A, Vieira JM, Gestri G, Denti L, Schwarz Q, Prykhozhij $S$ et al (2010) Tissue macrophages act as cellular chaperones for vascular anastomosis downstream of VEGF-mediated endothelial tip cell induction. Blood 1165:829-840. https://doi.org/10.1182/ blood-2009-12-257832

170. Diez-Roux G, Lang RA (1997) Macrophages induce apoptosis in normal cells in vivo. Development 12418:3633-3638

171. Shibata Y, Berclaz PY, Chroneos ZC, Yoshida M, Whitsett JA, Trapnell BC (2001) GM-CSF regulates alveolar macrophage differentiation and innate immunity in the lung through PU.1. Immunity 154:557-567. https://doi.org/10.1016/s1074-7613(01) 00218-7

172. Paolicelli RC, Bolasco G, Pagani F, Maggi L, Scianni M, Panzanelli $P$ et al (2011) Synaptic pruning by microglia is necessary for normal brain development. Science 3336048:1456-1458. https://doi. org/10.1126/science. 1202529

173. Odegaard JI, Ricardo-Gonzalez RR, Goforth MH, Morel CR, Subramanian V, Mukundan L et al (2007) Macrophage-specific PPARgamma controls alternative activation and improves insulin resistance. Nature 4477148:1116-1120. https://doi.org/10.1038/ nature 05894

174. Martel C, Li W, Fulp B, Platt AM, Gautier EL, Westerterp M et al (2013) Lymphatic vasculature mediates macrophage reverse cholesterol transport in mice. J Clin Investig 1234:1571-1579. https://doi.org/10.1172/JCI63685

175. Theurl I, Hilgendorf I, Nairz M, Tymoszuk P, Haschka D, Asshoff $\mathrm{M}$ et al (2016) On-demand erythrocyte disposal and iron recycling requires transient macrophages in the liver. Nat Med 228:945-951. https://doi.org/10.1038/nm.4146

176. Rabinovitch M (1995) Professional and non-professional phagocytes: an introduction. Trends Cell Biol 53:85-87. https://doi. org/10.1016/s0962-8924(00)88955-2

177. Lim JJ, Grinstein S, Roth Z (2017) Diversity and versatility of phagocytosis: roles in innate immunity, tissue remodeling, and homeostasis. Front Cell Infect Microbiol 7:191. https://doi.org/ 10.3389/fcimb.2017.00191

178. Pinto AR, Ilinykh A, Ivey MJ, Kuwabara JT, D’Antoni ML, Debuque R et al (2016) Revisiting cardiac cellular composition. Circ Res 1183:400-409. https://doi.org/10.1161/circresaha.115. 307778

179. Ramos GC, van den Berg A, Nunes-Silva V, Weirather J, Peters $\mathrm{L}$, Burkard M et al (2017) Myocardial aging as a T-cell-mediated phenomenon. Proc Natl Acad Sci U S A 11412:E2420-e2429. https://doi.org/10.1073/pnas.1621047114

180. Rieckmann M, Delgobo M, Gaal C, Büchner L, Steinau P, Reshef D et al (2019) Myocardial infarction triggers cardioprotective antigen-specific $\mathrm{T}$ helper cell responses. J Clin Invest 12911:4922-4936. https://doi.org/10.1172/jci123859 
181. Westermann D, Lindner D, Kasner M, Zietsch C, Savvatis $\mathrm{K}$, Escher $\mathrm{F}$ et al (2011) Cardiac inflammation contributes to changes in the extracellular matrix in patients with heart failure and normal ejection fraction. Circ Heart Fail 41:44-52. https:// doi.org/10.1161/circheartfailure.109.931451
Publisher's Note Springer Nature remains neutral with regard to jurisdictional claims in published maps and institutional affiliations. 